Bull. Fac. Agric., Cairo Univ., 68:305-318 (2017).

\title{
EFFECT OF CALCIUM AND SOME NUTRIENTS ON POMEGRANATE FRUIT CRACKING UNDER SOUHAG GOVERNORATE CONDITIONS
}

(Received: 24.12.2017)

\author{
By \\ T. Kh. El-Bolok and M. R. Sawarsan \\ Olive and Semi-Arid Fruits Department, Horticultural Research Institute, \\ Agricultural Research Center, Giza, Egypt
}

\begin{abstract}
The present experiment was conducted during 2013 and 2014 seasons, where two pomegranate cvs. Wardy and Manfalouty were subjected to single and combined applications of $\mathrm{ZnSO}_{4}(0.3 \%)$ as foliar application, soil application of $\left(\mathrm{CaSO}_{4}\right)$ at $500 \mathrm{~g} /$ tree and a mixture of micro elements (zinc, manganese, iron, cupper, boron, magnesium, sulfur and molybdenum) at $2 \mathrm{~g} / \mathrm{l}$ were added three times ( first of may, June and July). The selected pomegranate trees aged 9 year old grown in a sand-clay soil under flood irrigation system and spaced $6 \times 5$ meters apart in the experimental orchard of Horticulture Research Station, Shandaweel, Souhag Governorate, Egypt. The aim of the present study was to examine the effect of these nutrients on reducing fruit cracking and improving yield and fruit quality of pomegranate grown under Souhag Governorate conditions. Number of fruits/tree, marketable yield, fruit cracking \% and most characteristics of the fruits (physical and chemical) were higher in cv. Manfalouty relative to Wardy. As a conclusion, subjecting Wardy and Manfalouty pomegranate cvs. to combined applications of $\mathrm{ZnSO}_{4}(0.3 \%)$ as foliar application, soil application of $\left(\mathrm{CaSO}_{4}\right)$ at $500 \mathrm{~g} /$ tree and a mixture of micro elements as $2 \mathrm{~g} / \mathrm{l}$ are very effective in controlling fruit cracking, improving yield and fruit physical and chemical quality grown under Souhag environmental conditions.
\end{abstract}

Key words: Pomegranate, Wardy cv., Manfalouty cv., Nutrients, yield, Fruit quality, Fruit splitting.

\section{INTRODUCTION}

Pomegranate fruits have nutritional and some pharmacological values. They contain considerable amounts of citric acid, sugars, vitamins, minerals, amino acids, tannins, polyphenols, pigments and antioxidants, (Ahmed et al., 2009; Nita, 2009; Kharsandi et al., 2009; Dinkar, 2010; Ibrahim, 2010; Pedro et al., 2011 and Seidhom and Abd El-Rahman, 2011). The trees tolerate most unfavorable environmental conditions (Ed and Eric, 2007). Fruit cracking (splitting) is a serious problem and it is more intense in arid regions. This may be due to varietal characters, orchard soil management, and inappropriate levels of water at maturity stage, light, temperature, micro-nutrient deficiency and $\mathrm{Ca}$ (Rakesh et al., 2010). Cracking causes a major fruits loss, which is a serious commercial problem to the farmers; it causes loss of about $50 \%$ of the marketable fruits (Sheikh and Manjula, 2012). It is generally found in apricot, litchi, cherry, apple, pomegranate, citrus, and nectarine (Yadav et al.,
2014). All cracked fruits lose their value for fresh market and are used for processing only if they are not affected by fungus. Cracked fruits are susceptible to storage diseases and have short shelf-life (Rakesh et al., 2010). Although pomegranate is generally grown as a low input culture, varietal differences and some physiological disorders exert a major impact on fruit quality and consequently marketability to a great extent (Rakesh et al., 2010 and Abd ElRhman, 2010). Manfalouty pomegranate is the most important cultivar in Egypt and is subjected to fruit cracking (El-Khawaga, 2007 and Abd ElRhman, 2010). Fruit cracking is one of the physiological disorders, resulting in rind cracking and late fruit development wherever pomegranate trees are grown. It may be due to moisture imbalances as this fruit is very sensitive to variation in moisture. Prolonged drought causes hardening of peel, and if followed by heavy irrigation the pulp grows then peel grows and cracks (Hepaksoy et al., 2000). Zinc plays an important role in regulating absorption of 
water by plant roots (El-Khawaga, 2007). When $\mathrm{Zn}$ deficiency is evident, sprays should be applied to foliage in spring and early summer (Ed and Eric, 2007 and Sharma and Belsare, 2009). Foliar application of $\mathrm{ZnSo}_{4}$ and $\mathrm{MgSO}_{4}$ reduced the percentage of splitting pomegranate fruits while increased fruit yield per tree, juice acidity reduced TSS and sugars but did not reduce peel thickness (Kuldeep et al., 2001; John and Lauren, 2011). Fruit cracking may be due to boron deficiency in young fruits while in developed fruits it may be due to extreme variations in day and night temperatures. Spraying boron on the young fruits minimizes the incidence of fruit cracking (Ashwini, 2005; Sharma and Belsare 2009).

The current study was conducted to study the beneficial effects of some macro and micro elements on pomegranate fruit splitting and improving yield \& fruit quality of two commercial cultivars, named Wardy and Manfalouty, which are highly subject to fruit cracking.

\section{MATERIALS AND METHODS}

The present study was carried out during two successive seasons of 2013 and 2014. The selected pomegranate trees aged 9 years old grown in sand-clay soil (Table 1) under flood irrigation system and spaced $6 \times 5$ meters apart in an experimental orchard of Horticulture Research Station, Shandaweel, Souhag Governorate, Egypt. The selected trees had approximately the same vigour and grown under the same environmental conditions and cultural practices. Chemical analyses of the experimental soil are presented in Table (1).

This experiment included 16 treatments, which were the combination between two pomegranate cultivars (first factor) and eight fertilization treatments (second factor). The treatments were arranged in randomized complete block design (RCBD) in split plot with three replicates (one tree/each). The main plots were devoted to the two cultivars (Wardy and Manfalouty), while the sub plots were devoted to the fertilization treatments as follows:

1. Control (farm fertilization).

2. Foliar spraying with $\mathrm{ZnSO}_{4}(0.3 \%)$

3. Foliar spraying mix. of micronutrients (zinc, manganese, iron, cupper, boron, magnesium, sulfur and molybdenum) at $2 \mathrm{~g} / \mathrm{l}$.

4. Soil application of $\mathrm{CaSO}_{4}$ at $500 \mathrm{~g} / \mathrm{tree}$

5. Foliar spraying of $\mathrm{ZnSO}_{4}(0.3 \%)+$ mix. of micronutrients at $2 \mathrm{~g} / \mathrm{l}$.

6. Soil application of $\mathrm{CaSO}_{4}$ at $500 \mathrm{~g} /$ tree + foliar spraying with $\mathrm{ZnSO}_{4}(0.3 \%)$

7. Soil application of $\mathrm{CaSO}_{4}$ at $500 \mathrm{~g} /$ tree + foliar spraying with mix. of micronutrients at $2 \mathrm{~g} / \mathrm{l}$.

8. Soil application $\mathrm{CaSO}_{4}$ at $500 \mathrm{~g} /$ tree + foliar application of $\mathrm{ZnSO}_{4}(0.3 \%)+$ mix. of micronutrients at $2 \mathrm{~g} / \mathrm{l}$

All the selected trees (96 trees) received the fertilization program adopted in the farm where they were annually fertilized with organic manure at a rate of $20 \mathrm{~kg} /$ tree, plus $2 \mathrm{~kg}$ /tree super phosphate $\left(15.5 \% \mathrm{P}_{2} \mathrm{O}_{2}\right)$ in Dec. in a circle around the tree $(15 \mathrm{~cm}$. depth), all mixing together with the soil. Besides, $2 \mathrm{~kg} /$ tree ammonium nitrate $(33.5 \% \mathrm{~N})$ and potassium sulphate $\left(48 \% \quad \mathrm{~K}_{2} \mathrm{O}\right)$ as $1 \mathrm{~kg} /$ tree were applied and fractionated to three equal doses in March, May and August, by mixing with the soil surface $(15 \mathrm{~cm}$. depth). Calcium sulphate was applied as soil application around the perimeter of the tree after one month of fruit set. Zinc sulphate and the mixture of micronutrients were applied as foliar spraying three (May, June and July). The mixture of micronutrients contained chelated zinc $(3 \%)$, chelated manganese $(3 \%)$, chelated iron $(4 \%)$, chelated cupper $(0.5 \%)$, boron

Table (1): Chemical analyses of the experimental soil.

\begin{tabular}{|c|c|c|c|c|c|c|c|c|c|c|}
\hline \multirow{2}{*}{ PH } & \multirow{2}{*}{\multicolumn{2}{|c|}{$\begin{array}{c}\text { EC } \\
\text { (Mill mhos/cm) }\end{array}$}} & \multicolumn{8}{|c|}{ Saturation Extract (Mill equivalent/C) } \\
\hline & & & $\mathrm{Ca}^{++}$ & $\mathrm{Mg}^{++}$ & \multicolumn{2}{|c|}{$\mathrm{HCO}_{3}{ }^{-}$} & $\mathrm{CO}_{3}{ }^{=}$ & $\mathbf{K}^{+}$ & $\mathrm{Na}^{+}$ & $\mathrm{Cl}^{-}$ \\
\hline \multicolumn{11}{|c|}{$30-60 \mathrm{~cm}$ depth } \\
\hline 7.6 & 0.73 & \multicolumn{2}{|c|}{3.1} & 3.4 & \multicolumn{2}{|c|}{3.0} & - & 0.14 & 2.5 & 3 \\
\hline \multicolumn{11}{|c|}{$60-120 \mathrm{~cm}$ depth } \\
\hline & \multicolumn{2}{|c|}{0.69} & 2.5 & \multicolumn{2}{|c|}{1.6} & 3.5 & - & 0.17 & 3.3 & 4 \\
\hline & \multicolumn{9}{|c|}{ Table (1): Cont. } & \\
\hline & \multicolumn{7}{|c|}{ Available nutrient concentration (p.p.m.) } & \multicolumn{2}{|c|}{ Texture } & \\
\hline & $\mathbf{N}$ & $\overline{\mathbf{P}}$ & $\mathbf{K}$ & $\mathbf{F e}$ & Mn & $\mathbf{Z n}$ & $\mathrm{Cu}$ & \multirow{5}{*}{\multicolumn{2}{|c|}{ Sand - clay }} & \\
\hline & \multicolumn{7}{|c|}{$30-60 \mathrm{~cm}$ depth } & & & \\
\hline & 96.1 & 12.1 & 359 & 7.7 & 3.9 & 2.22 & 0.27 & & & \\
\hline & \multicolumn{7}{|c|}{$60-120 \mathrm{~cm}$ depth } & & & \\
\hline & 54.8 & 7.7 & 141 & 14.0 & 3.2 & 1.90 & 0.62 & & & \\
\hline
\end{tabular}


(1.5\%), magnesium (2\%), sulfur (1.6\%) and molybdenum $(0.05 \%)$. Triton $\mathrm{B}$, as a wetting agent, was added to all solutions at $0.1 \%$. Foliar application was done till runoff (51. /tree).

The following characters in both seasons were recorded:

\subsection{Yield per tree}

Pomegranate fruits of Wardy cv. were picked on the $15^{\text {th }}$ of August and Manfalouty cv. on the $15^{\text {th }}$ of September. Total fruit number/tree, fruit weight (gm.) were recorded and Av. total yield/ tree (Gross yield) were calculated as $\mathrm{kg}$. / tree. No. of cracked fruits /tree was counted and the percentage was calculated. Marketable fruits/tree (\%) was also calculated.

\subsection{Fruit quality characteristics}

A sample of fruits (three) of each replicate tree was randomly selected for determining the following physical and chemical properties:

\subsubsection{Fruit physical properties}

Fruit length \& diameter $(\mathrm{cm})$ and peel thickness $(\mathrm{cm})$ and weight $(\mathrm{gm})$ were measured. Number of aril/fruit was recorded. Percentages of fruit peel (\%) and juice (\%) were calculated.

\subsubsection{Fruit chemical properties}

Total soluble solids content (TSS \%) was measured. Total acidity (\%) expressed as gram citric acid/100 ml juice was recorded and T.S.S/acidity was calculated. Total and reducing sugars (\%) were determined (A.O.A.C., 1985). Tannin was determined in fruit juice by the method described by Winton and Winton (1945). Total anthocyanin (mg. /100 ml.) content in fruit juice was measured as described by Hsia et al., (1965).

\subsubsection{Statistical analysis}

All obtained data during the two seasons of study were statistically analyzed using the analysis of variance method according to Snedecor and Cochran (1980). Meanwhile, differences between means of treatments were compared using Duncan`s multiple range tested at probability of 0.05 level as reported by (Duncan, 1955).

\section{RESULTS AND DISCUSSION \\ 3.1. Yield per tree \\ 3.1.1. Number of fruits and yield/tree}

It is clear that, yield as the number of fruits and yield $(\mathrm{kg}) /$ tree, significantly increased by all treatments compared with the control in both seasons (Table 2). In this concern, soil application of $\mathrm{CaSO}_{4}$ at $500 \mathrm{~g} /$ tree + foliar spraying with a mixture of micronutrients at 2 $\mathrm{g} / \mathrm{l}$ with or without $\mathrm{ZnSO}_{4}$ foliar spraying at $0.3 \%$ proved to be the best treatment.

As related to the interaction effect of nutrient application treatments for both studied pomegranate cvs., the highest values of No. of fruits and yield were achieved with Manfalouty trees that treated with soil application $\left(\mathrm{CaSO}_{4}\right)$ at $500 \mathrm{gm} /$ tree $+\mathrm{ZnSO}_{4}$ spraying at $(0.3 \%)+$ spraying mix. of $(\mathrm{Mg}+\mathrm{Fe}+\mathrm{Zn}+\mathrm{Mn}+\mathrm{Cu}+\mathrm{B}$ + Mo $+\mathrm{S}$ ) at $2 \mathrm{~g} / \mathrm{l}$ during both seasons. Concerning the effect of cultivars, Manfalouty produced higher number of fruits and yield/tree than Wardy cv. during the two seasons. These results are in line with the findings of Singh and Maurya (2004). Who revealed that, foliar spray of micronutrients in combinations, i.e. $\mathrm{ZnSO}_{4}$ $(0.4 \%), \mathrm{FeSO}_{4}(0.4 \%), \mathrm{MnSO}_{4}(0.2 \%), \mathrm{H}_{3} \mathrm{BO}_{3}$ $(0.2 \%)$ and Mo at $(0.3 \%)$ gave a clear increase in both No. of fruits and yield of mango. Meanwhile, foliar application of $\mathrm{ZnSO}_{4}$ and $\mathrm{MgSO}_{4}$ increased fruit yield per tree (Kuldeep et al., 2001; John \& Lauren, 2011).

Mineral nutrition plays a vital role for the growth, yield and specially quality of fruits. It responses well to $\mathrm{Ca}, \mathrm{B}, \mathrm{Zn}$ to increase fruit yield, fruit weight and considerably decreases cracking which is one of the major disorders of pomegranate (Hoda and Hoda, 2013). These play a significant role in flowering, fruiting, nitrogen metabolism, hormone movement and its action and cell division. Boron increases fruit set of many species (Ashwini, 2005). Zinc is also an important nutrient element for growth, flowering and quality of fruits. It is involved in the biosynthesis of plant hormone indole acetic acid. Zinc plays an important role in nucleic acid and protein synthesis and helps in the utilization of phosphorous and nitrogen. Favorable effects of zinc sprays on vegetative growth and health of fruit trees have been observed in pomegranate (Pande et al., 2012).

\subsubsection{Marketable yield/tree and Cracking(\%)}

Using soil application of $\mathrm{CaSO}_{4}$ at $500 \mathrm{~g} /$ tree + spraying $\mathrm{ZnSO}_{4}$ at $(0.3 \%)+$ spraying mix. of micronutrients at $2 \mathrm{~g} / 1$ gave the maximum yield/tree $(\mathrm{kg})$ and yield $(\%)$ as they recorded $(67.50,70.80 \mathrm{~kg}$. \& 91.62, $90.96 \%)$. However, the control recorded the least records (39.90 \& $42.20 \mathrm{~kg}$. and $74.61 \& 75.36 \%$ ), respectively, in the first and second season. This is due to reducing fruit cracking (\%) and in turn increased marketable fruits as the control values were 25.50 and $24.70 \%$, respectively, to be decreased to $8.40 \& 9.10 \%$ in soil application of $\mathrm{CaSO}_{4}$ at 
Table (2): Effect of some nutrient applications on the number of fruits per tree and the total yield/tree (kg) of Wardy and Manfalouty pomegranates trees during 2013 and 2014 seasons.

\begin{tabular}{|c|c|c|c|c|c|c|c|}
\hline \multirow[b]{2}{*}{ No. } & \multirow[b]{2}{*}{ Treatments } & \multicolumn{3}{|c|}{ Number of fruits/tree } & \multicolumn{3}{|c|}{ Yield /tree (kg) } \\
\hline & & $\begin{array}{l}\text { Wardy } \\
\text { cv. }\end{array}$ & $\begin{array}{l}* * \text { Man. } \\
\text { cv. }\end{array}$ & $\begin{array}{c}\text { Mean } \\
\text { (B) }\end{array}$ & $\begin{array}{l}\text { Wardy } \\
\text { cv. }\end{array}$ & $\begin{array}{l}\text { **Man. } \\
\text { cv. }\end{array}$ & $\begin{array}{c}\text { Mean } \\
\text { (B) }\end{array}$ \\
\hline & & \multicolumn{6}{|c|}{ First season: 2013} \\
\hline T1 & Control (farm fertilization) & $141.0 \mathrm{p}$ & $162.0 \mathrm{j}$ & $151.5 \mathrm{H}$ & $41.70 \mathrm{p}$ & $64.80 \mathrm{~h}$ & $53.20 \mathrm{H}$ \\
\hline $\mathbf{T 2}$ & Foliar spraying with $\mathrm{ZnSO}_{4}(0.3 \%)$ & $144.1 \mathrm{o}$ & $166.0 \mathrm{~h}$ & $155.0 \mathrm{G}$ & $43.60 \mathrm{o}$ & $67.10 \mathrm{~g}$ & $55.30 \mathrm{G}$ \\
\hline $\mathbf{T 3}$ & $\begin{array}{l}\text { Foliar spraying with *mix. of micronutrients } \\
\text { at } 2 \mathrm{~g} / \mathrm{l}\end{array}$ & $152.2 \mathrm{~m}$ & $176.0 \mathrm{e}$ & $164.0 \mathrm{E}$ & $47.90 \mathrm{~m}$ & $73.60 \mathrm{e}$ & $60.60 \mathrm{E}$ \\
\hline $\mathbf{T 4}$ & Soil application of $\mathrm{CaSO}_{4}$ at $500 \mathrm{~g} /$ tree & $147.3 \mathrm{n}$ & $170.0 \mathrm{f}$ & $158.6 \mathrm{~F}$ & $45.50 \mathrm{n}$ & $69.70 \mathrm{f}$ & $57.60 \mathrm{~F}$ \\
\hline $\mathbf{T 5}$ & $\begin{array}{l}\text { Foliar spraying with } \mathrm{ZnSO}_{4}(0.3 \%)+\text { mix. } \\
\text { of micronutrients at } 2 \mathrm{~g} / \mathrm{l}\end{array}$ & 156.01 & $185.0 \mathrm{~d}$ & $170.5 \mathrm{D}$ & 50.201 & $78.80 \mathrm{~d}$ & $64.50 \mathrm{D}$ \\
\hline T6 & $\begin{array}{l}\text { Soil application of } \mathrm{CaSO}_{4} \text { at } 500 \mathrm{~g} / \text { tree + } \\
\text { foliar spraying with } \mathrm{ZnSO}_{4}(0.3 \%)\end{array}$ & $159.0 \mathrm{k}$ & $190.0 \mathrm{c}$ & $174.5 \mathrm{C}$ & $52.00 \mathrm{k}$ & $83.60 \mathrm{c}$ & $67.80 \mathrm{C}$ \\
\hline $\mathbf{T 7}$ & $\begin{array}{l}\text { Soil application of } \mathrm{CaSO}_{4} \text { at } 500 \mathrm{~g} / \mathrm{tree}+\text { foliar } \\
\text { spraying with mix. of micronutrients at } 2 \mathrm{~g} / \mathrm{l}\end{array}$ & $164.6 \mathrm{i}$ & $193.0 \mathrm{~b}$ & 178.8 B & $54.70 \mathrm{j}$ & $86.80 \mathrm{~b}$ & 70.70 B \\
\hline T8 & $\begin{array}{l}\text { Soil application } \mathrm{CaSO}_{4} \text { at } 500 \text { g/tree }+ \text { foliar } \\
\text { spraying } \mathrm{ZnSO}_{4}(0.3 \%)+\text { mix. of micronutrients } \\
\text { at } 2 \mathrm{~g} / \mathrm{l}\end{array}$ & $168.0 \mathrm{~g}$ & $197.0 \mathrm{a}$ & $182.5 \mathrm{~A}$ & $56.80 \mathrm{i}$ & $90.40 \mathrm{a}$ & 73.60 A \\
\hline \multicolumn{2}{|r|}{$\operatorname{Mean}(A)$} & $154.0 \mathrm{~B}$ & $179.0 \mathrm{~A}$ & & 49.10 B & $76.90 \mathrm{~A}$ & \\
\hline & & \multicolumn{6}{|c|}{ Second season: 2014} \\
\hline T1 & Control (farm fertilization) & $147.0 \mathrm{o}$ & $168.0 \mathrm{k}$ & $157.5 \mathrm{H}$ & $44.20 \mathrm{p}$ & $67.50 \mathrm{~h}$ & $55.80 \mathrm{H}$ \\
\hline $\mathbf{T 2}$ & Foliar spraying with $\mathrm{ZnSO}_{4}(0.3 \%)$ & $149.0 \mathrm{n}$ & $174.0 \mathrm{i}$ & $161.5 \mathrm{G}$ & $45.70 \mathrm{o}$ & $71.00 \mathrm{~g}$ & $58.30 \mathrm{G}$ \\
\hline $\mathbf{T 3}$ & $\begin{array}{l}\text { Foliar spraying with *mix. of micronutrients at } 2 \\
\text { g/l }\end{array}$ & 164.01 & $181.0 \mathrm{f}$ & $172.5 \mathrm{E}$ & $52.50 \mathrm{~m}$ & $76.00 \mathrm{e}$ & $64.20 \mathrm{E}$ \\
\hline $\mathbf{T 4}$ & Soil application of $\mathrm{CaSO}_{4}$ at $500 \mathrm{~g} /$ tree & $155.0 \mathrm{~m}$ & $178.0 \mathrm{~g}$ & $166.5 \mathrm{~F}$ & $48.50 n$ & $73.60 \mathrm{f}$ & $61.00 \mathrm{~F}$ \\
\hline T5 & $\begin{array}{l}\text { Foliar spraying with } \mathrm{ZnSO}_{4}(0.3 \%)+\text { mix. of } \\
\text { micronutrients at } 2 \mathrm{~g} / \mathrm{l}\end{array}$ & $172.0 \mathrm{j}$ & $186.0 \mathrm{~d}$ & 179.0 D & 56.201 & $79.60 \mathrm{~d}$ & 67.90 D \\
\hline T6 & $\begin{array}{l}\text { Soil application of } \mathrm{CaSO}_{4} \text { at } 500 \mathrm{~g} / \text { tree }+ \text { foliar } \\
\text { spraying with } \mathrm{ZnSO}_{4}(0.3 \%)\end{array}$ & $176.0 \mathrm{~h}$ & $191.0 \mathrm{c}$ & $183.5 \mathrm{C}$ & $58.80 \mathrm{k}$ & $83.80 \mathrm{c}$ & $71.30 \mathrm{C}$ \\
\hline $\mathbf{T 7}$ & $\begin{array}{l}\text { Soil application of } \mathrm{CaSO}_{4} \text { at } 500 \mathrm{~g} / \text { tree }+ \text { foliar } \\
\text { spraying with mix. of micronutrients at } 2 \mathrm{~g} / \mathrm{l}\end{array}$ & $181.0 \mathrm{f}$ & $195.0 \mathrm{~b}$ & 188.0 B & $61.50 \mathrm{j}$ & $87.20 \mathrm{~b}$ & $74.30 \mathrm{~B}$ \\
\hline T8 & $\begin{array}{l}\text { Soil application } \mathrm{CaSO}_{4} \text { at } 500 \text { g/tree }+ \text { foliar } \\
\text { spraying } \mathrm{ZnSO}_{4}(0.3 \%)+\text { mix. of micronutrients } \\
\text { at } 2 \mathrm{~g} / \mathrm{l}\end{array}$ & $184.0 \mathrm{e}$ & $200.0 \mathrm{a}$ & 192.0 A & $63.50 \mathrm{i}$ & $92.00 \mathrm{a}$ & $77.70 \mathrm{~A}$ \\
\hline & Mean (A) & $166.0 \mathrm{~B}$ & $184.1 \mathrm{~A}$ & & 53.90 B & $78.80 \mathrm{~A}$ & \\
\hline
\end{tabular}

Means followed by the same letter in a column or row do not differ significantly according to Duncan's New

Multiple Range Test at $\mathrm{P}=0.05$

$*$ mix. of micronutrients $=(\mathrm{Mg}+\mathrm{Fe}+\mathrm{Zn}+\mathrm{Mn}+\mathrm{Cu}+\mathrm{B}+\mathrm{Mo}+\mathrm{S}) \quad * * \mathrm{Man} .=$ Manfalouty cultivar

$(\mathrm{A})=$ Cultivars $(\mathrm{B})=$ Nutrient applications

$500 \mathrm{~g} /$ tree + spraying $\mathrm{ZnSO}_{4}$ at $(0.3 \%)+$ spraying mix. of micronutrients at $2 \mathrm{~g} / \mathrm{l}$ treatment, in both seasons, respectively.

Regarding the cultivars, Manfalouty was better during the two seasons for marketable fruits as $\mathrm{kg}$ and percentage, whereas Wardy cultivar gave higher fruit cracking (\%) in both seasons. As for the interaction between treatments and cultivars, treated Manfalouty trees with $\mathrm{CaSO}_{4}$ at $500 \mathrm{~g} /$ tree as soil application + spraying $\mathrm{ZnSO}_{4}$ at $0.3 \%+$ spraying mix. of micronutrients at $2 \mathrm{~g} / 1$ gave the highest values of marketable yield/tree as $(\mathrm{kg})$ or $\%$, while Wardy cv. with the control treatment took the other way around, during both studied seasons. The opposite trend was observed with cracking fruit percentage.

Crop quality characteristics mostly reported to be affected by plant nutrition. It has been noted that essential and beneficial nutrient elements contribute to crop quality through functioning as raw materials for the synthesis of various plant components. Sheikh and Manjula (2012) mentioned that nutrients like boron, zinc, calcium, copper, molybdenum manganese and potash are involved in physiological processes during fruit growth period, and their deficiencies cause cracking. Boron and copper help to 
increase the growth rate by stimulating enzymatic action in the peripheral tissue which otherwise could not be due to their inherent deficiency in the area. Boron application may probably help in the translocation of sugars and synthesis of cell wall. In addition, Koriem et al. (1994) reported that gypsum treatment was superior in decreasing EC, soluble ions, ESP, exchangeable $\mathrm{Mg}$ percentage and increasing exchangeable $\mathrm{Ca}$ percentage as well as improving all physical properties. Micronutrients such as $\mathrm{Fe}, \mathrm{B}, \mathrm{Mn}$ and $\mathrm{Zn}$ when sprayed in combinations were found promising whereas B reduced the percentage of cracked fruits (Sheikh and Manjula (2012). In addition, Tanuja and
Rawat (2016) confirmed that boron plays a significant role in nitrogen metabolism, hormone movement and its action, and cell division. Its deficiency results in cracking of fruits. They also, mentioned that nutrients like potassium, zinc, copper, molybdenum and manganese are involved in some physiological processes during the fruit growth period and their deficiency results in fruit cracking. The importance of $\mathrm{Ca}$ as a component of chlorophyll molecule as well as the role in cell division and pollen grain germination may illustrate the effect of the tested macronutrients in improving the yield and fruit physical characters (Morsy et al., 2008).

Table (3): Effect of some nutrient applications on marketable yield/tree (kg), cracking fruits (\%) and marketable yield $(\%)$ of Wardy and Manfalouty pomegranates trees during 2013 and 2014 seasons.

\begin{tabular}{|c|c|c|c|c|c|c|c|c|c|c|}
\hline \multirow[b]{2}{*}{ No. } & \multirow[b]{2}{*}{ Treatments } & \multicolumn{3}{|c|}{ Marketable yield/tree (kg) } & \multicolumn{3}{|c|}{ Cracking fruits $(\%)$} & \multicolumn{3}{|c|}{ Marketable yield (\%) } \\
\hline & & \begin{tabular}{|c|}
$\begin{array}{c}\text { Wardy } \\
\text { cv. }\end{array}$ \\
\end{tabular} & \begin{tabular}{|c|}
$* *$ Man. \\
cv.
\end{tabular} & $\begin{array}{c}\text { Mean } \\
\text { (B) }\end{array}$ & $\begin{array}{c}\text { Wardy } \\
\text { cv. }\end{array}$ & $\begin{array}{l}* * \text { Man. } \\
\text { cv. }\end{array}$ & $\begin{array}{c}\text { Mean } \\
\text { (B) }\end{array}$ & \begin{tabular}{|c|} 
Wardy \\
cv.
\end{tabular} & \begin{tabular}{|c|}
$* *$ Man. \\
cv.
\end{tabular} & $\begin{array}{c}\text { Mean } \\
\text { (B) }\end{array}$ \\
\hline \multicolumn{11}{|c|}{ First season: 2013} \\
\hline T1 & Control (farm fertilization) & $30.50 \mathrm{o}$ & $49.30 \mathrm{~h}$ & $39.90 \mathrm{H}$ & $26.90 \mathrm{a}$ & $24.00 \mathrm{c}$ & $25.50 \mathrm{~A}$ & $73.14 \mathrm{i}$ & $76.08 \mathrm{~h}$ & $74.61 \mathrm{G}$ \\
\hline $\mathbf{T 2}$ & Foliar spraying with $\mathrm{ZnSO}_{4}(0.3 \%)$ & $32.00 \mathrm{n}$ & $52.30 \mathrm{~g}$ & $42.10 \mathrm{G}$ & $25.60 \mathrm{~b}$ & $22.00 \mathrm{e}$ & $23.80 \mathrm{~B}$ & $73.39 \mathrm{i}$ & $77.94 \mathrm{~g}$ & $75.67 \mathrm{G}$ \\
\hline T3 & \begin{tabular}{|l}
$\begin{array}{l}\text { Foliar spraying with } \\
\text { micronutrients at } 2 \mathrm{~g} / \mathrm{l}\end{array}$ \\
\end{tabular} & 36.901 & $60.00 \mathrm{e}$ & $48.45 \mathrm{E}$ & $22.90 \mathrm{~d}$ & $18.50 \mathrm{~h}$ & 20.70 D & 77.34gh & $81.52 \mathrm{de}$ & 79.43E \\
\hline T4 & Soil application of $\mathrm{CaSO}_{4}$ at $500 \mathrm{~g} /$ tree & $34.60 \mathrm{~m}$ & $55.80 \mathrm{f}$ & $45.20 \mathrm{~F}$ & $23.90 \mathrm{c}$ & $20.00 \mathrm{~g}$ & $22.00 \mathrm{C}$ & $76.04 \mathrm{~h}$ & $80.06 \mathrm{ef}$ & $78.05 \mathrm{~F}$ \\
\hline T5 & \begin{tabular}{|l|} 
Foliar spraying with $\mathrm{ZnSO}_{4}(0.3 \%)+$ \\
mix. of micronutrients at $2 \mathrm{~g} / \mathrm{l}$ \\
\end{tabular} & $39.70 \mathrm{k}$ & $65.50 \mathrm{~d}$ & $52.60 \mathrm{D}$ & $21.00 \mathrm{f}$ & $16.90 \mathrm{i}$ & $19.00 \mathrm{E}$ & $79.08 \mathrm{fg}$ & $83.12 \mathrm{~d}$ & 81.10D \\
\hline T6 & \begin{tabular}{|l|}
$\begin{array}{l}\text { Soil application of } \mathrm{CaSO}_{4} \text { at } 500 \mathrm{~g} / \text { tree }+ \\
\text { foliar spraying with } \mathrm{ZnSO}_{4}(0.3 \%)\end{array}$ \\
\end{tabular} & $43.10 \mathrm{j}$ & $71.60 \mathrm{c}$ & $57.30 \mathrm{C}$ & $17.10 \mathrm{i}$ & $14.30 \mathrm{j}$ & $15.70 \mathrm{~F}$ & $82.88 \mathrm{~d}$ & $85.65 \mathrm{c}$ & $84.26 \mathrm{C}$ \\
\hline T7 & $\begin{array}{l}\text { Soil application of } \mathrm{CaSO}_{4} \text { at } 500 \mathrm{~g} / \text { tree + } \\
\text { foliar spraying with mix. of } \\
\text { micronutrients at } 2 \mathrm{~g} / \mathrm{l}\end{array}$ & $47.50 \mathrm{i}$ & $78.20 \mathrm{~b}$ & $62.80 \mathrm{~B}$ & $13.10 \mathrm{k}$ & 9.901 & $11.50 \mathrm{G}$ & $86.84 \mathrm{c}$ & $90.09 \mathrm{~b}$ & 88.46B \\
\hline T8 & $\begin{array}{l}\text { Soil application } \mathrm{CaSO}_{4} \text { at } 500 \mathrm{~g} / \text { tree }+ \\
\text { foliar spraying } \mathrm{ZnSO}_{4}(0.3 \%)+\text { mix. of } \\
\text { micronutrients at } 2 \mathrm{~g} /\end{array}$ & $51.80 \mathrm{~g}$ & $83.20 \mathrm{a}$ & $67.50 \mathrm{~A}$ & $8.80 \mathrm{~m}$ & $8.00 \mathrm{n}$ & $8.40 \mathrm{H}$ & $91.20 \mathrm{ab}$ & $92.04 \mathrm{a}$ & 91.62A \\
\hline \multicolumn{2}{|r|}{$\operatorname{Mean}(\mathbf{A})$} & $39.50 \mathrm{~B}$ & $64.50 \mathrm{~A}$ & & $19.90 \mathrm{~A}$ & 16.70B & & 79.99B & 83.31A & \\
\hline & & \multicolumn{9}{|c|}{ Second season: 2014} \\
\hline T1 & Control (farm fertilization) & $32.70 \mathrm{n}$ & $51.80 \mathrm{~h}$ & $42.20 \mathrm{H}$ & $26.00 \mathrm{a}$ & $23.30 \mathrm{c}$ & $24.70 \mathrm{~A}$ & $73.98 \mathrm{k}$ & $76.74 \mathrm{ij}$ & $75.36 \mathrm{H}$ \\
\hline T2 & Foliar spraying with $\mathrm{ZnSO}_{4}(\mathbf{0 . 3 \%})$ & $34.40 \mathrm{~m}$ & $55.40 \mathrm{~g}$ & $44.90 \mathrm{G}$ & $24.70 \mathrm{~b}$ & $22.00 \mathrm{~d}$ & 23.40 B & $75.27 \mathrm{jk}$ & $78.03 \mathrm{hi}$ & $76.65 \mathrm{G}$ \\
\hline T3 & $\begin{array}{|lll|}\begin{array}{l}\text { Foliar spraying with } \\
\text { micronutrients at } 2 \mathrm{~g} / \mathrm{l}\end{array} & & \\
\end{array}$ & $41.00 \mathrm{k}$ & $61.60 \mathrm{e}$ & $51.30 \mathrm{E}$ & $21.90 \mathrm{~d}$ & $19.00 \mathrm{~g}$ & 20.50 D & $78.10 \mathrm{hi}$ & 81.05 ef & $79.57 \mathrm{E}$ \\
\hline T4 & Soil application of $\mathrm{CaSO}_{4}$ at $500 \mathrm{~g} /$ tree & 37.301 & $58.30 \mathrm{f}$ & $80 \mathrm{~F}$ & $23.00 \mathrm{c}$ & $20.80 \mathrm{e}$ & $21.90 \mathrm{C}$ & $76.91 \mathrm{ij}$ & $79.21 \mathrm{gh}$ & $78.06 \mathrm{~F}$ \\
\hline T5 & \begin{tabular}{|l|}
$\begin{array}{l}\text { Foliar spraying with } \mathrm{ZnSO}_{4}(0.3 \%)+ \\
\text { mix. of micronutrients at } 2 \mathrm{~g} / \mathrm{l}\end{array}$ \\
\end{tabular} & $45.00 \mathrm{j}$ & $65.50 \mathrm{~d}$ & $55.20 \mathrm{D}$ & $20.00 \mathrm{f}$ & $17.70 \mathrm{~h}$ & $18.90 \mathrm{E}$ & $80.07 \mathrm{fg}$ & $82.32 \mathrm{e}$ & 81.20 D \\
\hline T6 & \begin{tabular}{|l|}
$\begin{array}{l}\text { Soil application of } \mathrm{CaSO}_{4} \text { at } 500 \mathrm{~g} / \text { tree }+ \\
\text { foliar spraying with } \mathrm{ZnSO}_{4}(0.3 \%)\end{array}$ \\
\end{tabular} & $49.90 \mathrm{i}$ & $72.00 \mathrm{c}$ & $60.70 \mathrm{C}$ & $16.00 \mathrm{i}$ & $14.00 \mathrm{j}$ & $15.00 \mathrm{~F}$ & $84.86 \mathrm{~d}$ & $85.92 \mathrm{~d}$ & $85.39 \mathrm{C}$ \\
\hline T7 & \begin{tabular}{|l|} 
Soil application of $\mathrm{CaSO}_{4}$ at $500 \mathrm{~g} /$ tree + \\
foliar spraying with mix. of \\
micronutrients at $2 \mathrm{~g} / \mathrm{l}$
\end{tabular} & $54.10 \mathrm{~g}$ & $77.70 \mathrm{~b}$ & $65.90 \mathrm{~B}$ & $12.00 \mathrm{k}$ & 10.901 & $11.50 \mathrm{G}$ & $87.96 \mathrm{c}$ & $89.11 \mathrm{bc}$ & 88.54 B \\
\hline T8 & $\begin{array}{l}\text { Soil application } \mathrm{CaSO}_{4} \text { at } 500 \mathrm{~g} / \text { tree }+ \\
\text { foliar spraying } \mathrm{ZnSO}_{4}(0.3 \%)+\text { mix. of } \\
\text { micronutrients at } 2 \mathrm{~g} / \mathrm{l}\end{array}$ & $57.40 \mathrm{f}$ & $84.20 \mathrm{a}$ & $70.80 \mathrm{~A}$ & $9.60 \mathrm{~m}$ & $8.50 \mathrm{n}$ & $9.10 \mathrm{H}$ & $90.39 \mathrm{ab}$ & $91.52 \mathrm{a}$ & $90.96 \mathrm{~A}$ \\
\hline & $\operatorname{Mean}(A)$ & 43.90 B & $65.80 \mathrm{~A}$ & & $19.20 \mathrm{~A}$ & 17.00B & & $80.94 \mathrm{~B}$ & $82.99 \mathrm{~A}$ & \\
\hline
\end{tabular}

Means followed by the same letter in a column or row do not differ significantly according to Duncan's New

Multiple Range Test at $\mathrm{P}=0.05$

*mix. of micronutrients $=(\mathrm{Mg}+\mathrm{Fe}+\mathrm{Zn}+\mathrm{Mn}+\mathrm{Cu}+\mathrm{B}+\mathrm{Mo}+\mathrm{S})$

**Man. = Manfalouty cultivar

(A) $=$ Cultivars $(B)=$ Nutrient applications 


\subsection{Fruit quality characteristics}

\subsubsection{Fruit weight and fruit peel weight}

Data in Table (4) show that, all treatments significantly increased fruit weight ( $\mathrm{g}$ ) compared with the control trees in both seasons. Manfalouty cultivar gave significantly higher fruit weight in the first and second seasons. As for the interaction between treatments and cultivar, the highest values of fruit weight came with using soil application of $\mathrm{CaSO}_{4}$ at 500 $\mathrm{g} /$ tree+ foliar spraying $\mathrm{ZnSO}_{4}$ at $0.3 \%+$ spraying mix. of micronutrients at $2 \mathrm{~g} / \mathrm{l}$ of Manfalouty cultivar.

With concern to fruit peel weight, (irrespective of the control) all treatments showed insignificantly differences between them. However they showed positive effect when compared with the control in both seasons. Regarding the interaction between treatments and cultivar, generally, Manfalouty cv. with all treatments, including the control, gave higher values of fruit peel weight \% than Wardy $\mathrm{cv}$. This was true in the two seasons of study.

Hoda and Hoda (2013) demonstrated that the pomegranate fruit weight and yield were increased by using $(3 \% \mathrm{Ca}+0.3 \% \mathrm{~B}+0.3 \% \mathrm{Zn})$. The better fruit weight with boron and zinc treatments might be due to boron role in cell division, cell elongation, sugar metabolism and accumulation of carbohydrates (Sourour 2000).

Table (4): Effect of some nutrient applications on fruit weight (g) and fruit peel weight (\%) of Wardy and Manfalouty pomegranate trees during 2013 and 2014 seasons.

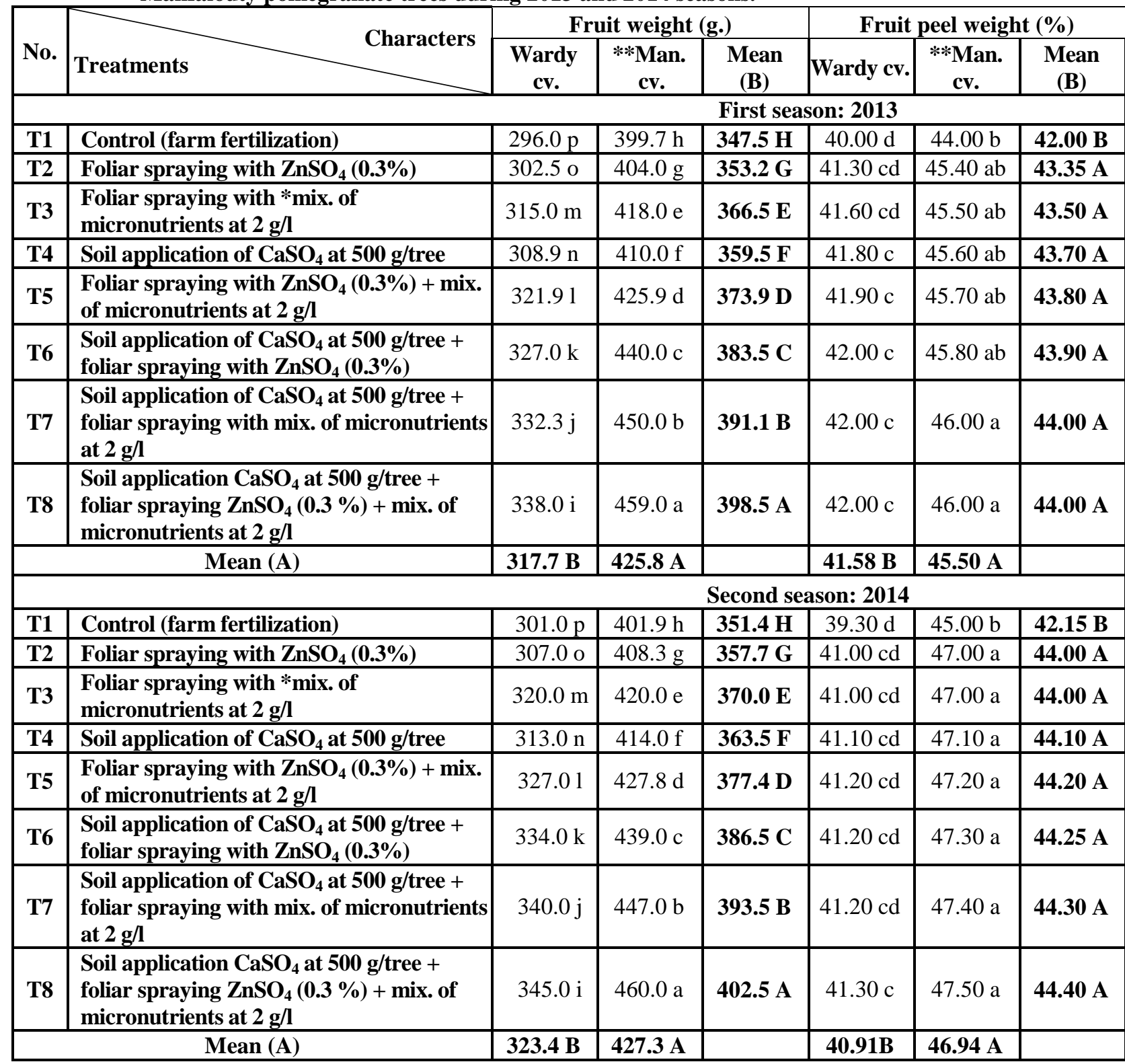

Means followed by the same letter in a column or row do not differ significantly according to Duncan's New Multiple Range Test at $\mathrm{P}=0.05$

$*$ mix. of micronutrients $=(\mathrm{Mg}+\mathrm{Fe}+\mathrm{Zn}+\mathrm{Mn}+\mathrm{Cu}+\mathrm{B}+\mathrm{Mo}+\mathrm{S}) \quad * *$ Man. $=$ Manfalouty cultivar

(A) $=$ Cultivars $(\mathrm{B})=$ Nutrient applications 
Zinc has been identified as a component of almost 60 enzymes and it has a role in the synthesis of growth promoter hormone in fruits (Shivanandam et al., 2007).

\subsubsection{Fruit dimensions (cm)}

According to the results in Table (5), most treatments significantly increased fruit length $(\mathrm{cm})$ and diameter $(\mathrm{cm})$ than the control in the two seasons. In this respect, soil application of $\mathrm{CaSO}_{4}$ at $500 \mathrm{~g} /$ tree + foliar spraying mix. of micronutrients at $2 \mathrm{~g} / 1$ with or without spraying $\mathrm{ZnSO}_{4}$ at $0.3 \%$ proved to be the best treatments.

The interaction between cultivars and treatments, when Manfalouty cv. was subjected to the aforementioned treatments, produced the highest values of fruit length and diameter. As for cultivars, Manfalouty cultivar gave higher values than Wardy cv. These results were true in both seasons of study.

Singh et al. (2001) achieved the highest fruit length and fruit width of aonla (Francis cv.) when $\mathrm{ZnSO}_{4}(0.5 \%)$, borax $(0.2 \%)$, CuSO4 $(0.4 \%)$ and their combinations were applied. Rani and Brahmachari (2001) found the same results on litchi. In addition, Korkmaz and Askn (2015) proved that both calcium and boron foliar application on pomegranate resulted in increased fruit size and length.

\subsubsection{Fruit peel thickness $(\mathrm{cm})$, aril weight} (\%) and No. of arils/ fruit

From the data presented in Table (6), values of fruit peel thickness showed clear insignificant differences between tested treatments (except the control). The least records showed in the control

Table (5): Effect of some nutrient applications on fruit length and diameter (cm) of Wardy and Manfalouty pomegranate trees during 2013 and 2014 seasons.

\begin{tabular}{|c|c|c|c|c|c|c|c|}
\hline \multirow[b]{2}{*}{ No. } & \multirow[b]{2}{*}{ Treatments } & \multicolumn{3}{|c|}{ Fruit length $(\mathrm{cm})$} & \multicolumn{3}{|c|}{ Fruit diameter $(\mathrm{cm})$} \\
\hline & & \begin{tabular}{|c|}
$\begin{array}{c}\text { Wardy } \\
\text { cv. }\end{array}$ \\
\end{tabular} & $\begin{array}{c}* * \text { Man. } \\
\text { cv. }\end{array}$ & $\begin{array}{c}\text { Mean } \\
\text { (B) }\end{array}$ & $\begin{array}{c}\text { Wardy } \\
\text { cv. }\end{array}$ & $\begin{array}{c}* * * \text { Man. } \\
\text { cv. }\end{array}$ & $\begin{array}{l}\text { Mean } \\
\text { (B) }\end{array}$ \\
\hline \multicolumn{8}{|c|}{ First season: 2013} \\
\hline T1 & $\begin{array}{l}\text { Control (farm fertilization) } \\
\text { (f) }\end{array}$ & $6.20 \mathrm{k}$ & $7.20 \mathrm{f}-\mathrm{h}$ & $6.70 \mathrm{G}$ & $6.00 \mathrm{~m}$ & $7.60 \mathrm{~g}-\mathrm{i}$ & $6.80 \mathrm{~F}$ \\
\hline T2 & Foliar spraying with $\mathrm{ZnSO}_{4}(\mathbf{0 . 3 \%})$ & $6.40 \mathrm{jk}$ & $7.50 \mathrm{e}-\mathrm{g}$ & $6.95 \mathrm{FG}$ & 6.401 & $7.80 \mathrm{f}-\mathrm{h}$ & $7.10 \mathrm{E}$ \\
\hline T3 & Foliar spraying with *mix. of micronutrients at $2 \mathrm{~g} / \mathrm{l}$ & $6.80 \mathrm{~h}-\mathrm{j}$ & $7.90 \mathrm{c}-\mathrm{e}$ & $7.35 \mathrm{DE}$ & $7.00 \mathrm{jk}$ & $8.40 \mathrm{de}$ & $7.70 \mathrm{C}$ \\
\hline T4 & Soil application of $\mathrm{CaSO}_{4}$ at $500 \mathrm{~g} /$ tree & $6.60 \mathrm{i}-\mathrm{k}$ & $7.70 \mathrm{~d}-\mathrm{f}$ & $7.15 \mathrm{EF}$ & $6.70 \mathrm{kl}$ & $8.10 \mathrm{ef}$ & $7.40 \mathrm{D}$ \\
\hline T5 & $\begin{array}{l}\text { Foliar spraying with } \mathrm{ZnSO}_{4}(0.3 \%)+\text { mix. of } \\
\text { micronutrients at } 2 \mathrm{~g} / \mathrm{l}\end{array}$ & $7.10 \mathrm{~g}-\mathrm{i}$ & $8.10 \mathrm{~b}-\mathrm{d}$ & $7.60 \mathrm{CD}$ & $7.20 \mathrm{ij}$ & $8.70 \mathrm{~cd}$ & $7.95 \mathrm{C}$ \\
\hline T6 & $\begin{array}{l}\text { Soil application of } \mathrm{CaSO}_{4} \text { at } 500 \mathrm{~g} / \text { tree + foliar spraying } \\
\text { with } \mathrm{ZnSO}_{4}(0.3 \%)\end{array}$ & $7.40 \mathrm{e}-\mathrm{g}$ & $8.40 \mathrm{a}-\mathrm{c}$ & $7.90 \mathrm{BC}$ & $7.50 \mathrm{hi}$ & $9.00 \mathrm{bc}$ & $8.25 \mathrm{~B}$ \\
\hline T7 & $\begin{array}{l}\text { Soil application of } \mathrm{CaSO}_{4} \text { at } 500 \mathrm{~g} / \text { tree + foliar spraying } \\
\text { with mix. of micronutrients at } 2 \mathrm{~g} / \mathrm{l}\end{array}$ & $7.60 \mathrm{~d}-\mathrm{g}$ & $8.60 \mathrm{ab}$ & $8.10 \mathrm{AB}$ & $7.70 \mathrm{f}-\mathrm{h}$ & $9.30 \mathrm{ab}$ & $8.50 \mathrm{AB}$ \\
\hline T8 & $\begin{array}{l}\text { Soil application } \mathrm{CaSO}_{4} \text { at } 500 \mathrm{~g} / \text { tree + foliar spraying } \\
\mathrm{ZnSO}_{4}(0.3 \%)+\text { mix. of micronutrients at } 2 \mathrm{~g} / 1\end{array}$ & $7.80 \mathrm{de}$ & $8.80 \mathrm{a}$ & $8.30 \mathrm{~A}$ & $8.00 \mathrm{e}-\mathrm{g}$ & $9.50 \mathrm{a}$ & $8.75 \mathrm{~A}$ \\
\hline \multirow{2}{*}{\multicolumn{8}{|c|}{\begin{tabular}{|l|l|l|} 
& $7.06 \mathrm{~B}$ & $8.55 \mathrm{~A}$ \\
\end{tabular}}} \\
\hline & & & & & & & \\
\hline T1 & Control (farm fertilizat & 6.001 & $7.30 \mathrm{~g}-\mathrm{i}$ & 6.65G & $5.80 \mathrm{i}$ & $7.70 \mathrm{e}$ & $6.75 \mathrm{~F}$ \\
\hline T2 & Foliar spraying with $\mathrm{ZnSO}_{4}(0.3 \%)$ & $6.20 \mathrm{kl}$ & $7.60 \mathrm{f}-\mathrm{h}$ & $6.90 \mathrm{FG}$ & $6.10 \mathrm{hi}$ & $7.90 \mathrm{de}$ & $7.00 \mathrm{E}$ \\
\hline T3 & Foliar s & $6.60 \mathrm{jk}$ & $8.10 \mathrm{de}$ & 7.35DE & $6.60 \mathrm{fg}$ & $8.50 \mathrm{~d}$ & $7.55 \mathrm{D}$ \\
\hline T4 & Soil application of $\mathrm{CaSO}_{4}$ at $500 \mathrm{~g} /$ tree & $6.40 \mathrm{kl}$ & 7.80 ef & 7.10EF & $6.40 \mathrm{gh}$ & $8.20 \mathrm{~d}$ & $7.30 \mathrm{D}$ \\
\hline T5 & $\begin{array}{l}\text { Foliar spraying with } \mathrm{ZnSO}_{4}(0.3 \%)+\text { mix. of } \\
\text { micronutrients at } 2 \mathrm{~g} / \mathrm{l}\end{array}$ & $7.00 \mathrm{ij}$ & $8.30 \mathrm{~cd}$ & 7.65CD & $6.90 \mathrm{f}$ & $8.70 \mathrm{c}$ & $7.80 \mathrm{C}$ \\
\hline T6 & $\begin{array}{l}\text { Soil application of } \mathrm{CaSO}_{4} \text { at } 500 \mathrm{~g} / \mathrm{tree}+\text { foliar spraying } \\
\text { with } \mathrm{ZnSO}_{4}(0.3 \%)\end{array}$ & $7.20 \mathrm{hi}$ & $8.60 \mathrm{bc}$ & $7.90 \mathrm{BC}$ & $6.40 \mathrm{gh}$ & $8.90 \mathrm{bc}$ & $8.10 \mathrm{~B}$ \\
\hline T7 & $\begin{array}{l}\text { Soil application of } \mathrm{CaSO}_{4} \text { at } 500 \mathrm{~g} / \mathrm{tree}+\text { foliar spraying } \\
\text { with mix. of micronutrients at } 2 \mathrm{~g} / 1\end{array}$ & $7.50 \mathrm{f}-\mathrm{h}$ & $8.80 \mathrm{ab}$ & 8.10AB & $7.70 \mathrm{e}$ & $9.20 \mathrm{ab}$ & $8.40 \mathrm{AB}$ \\
\hline T8 & $\begin{array}{l}\text { Soil application } \mathrm{CaSO}_{4} \text { at } 500 \mathrm{~g} / \text { tree + foliar spraying } \\
\mathrm{ZnSO}_{4}(0.3 \%)+\text { mix. of micronutrients at } 2 \mathrm{~g} / 1\end{array}$ & $7.70 \mathrm{e}-\mathrm{g}$ & $9.10 \mathrm{a}$ & $8.40 \mathrm{~A}$ & $7.90 \mathrm{de}$ & $9.40 \mathrm{a}$ & $8.60 \mathrm{~A}$ \\
\hline & Mean (A) & $6.83 \mathrm{~B}$ & $8.20 \mathrm{~A}$ & & \begin{tabular}{|c|}
$6.73 \mathrm{~B}$ \\
\end{tabular} & $8.60 \mathrm{~A}$ & \\
\hline
\end{tabular}

Means followed by the same letter in a column or row do not differ significantly according to Duncan's New

Multiple Range Test at $\mathrm{P}=0.05$

$*$ mix. of micronutrients $=(\mathrm{Mg}+\mathrm{Fe}+\mathrm{Zn}+\mathrm{Mn}+\mathrm{Cu}+\mathrm{B}+\mathrm{Mo}+\mathrm{S}) \quad * *$ Man. $=$ Manfalouty cultivar

(A) $=$ Cultivars $(\mathrm{B})=$ Nutrient applications 
when compared with other treatments during the two growing seasons. Regarding the interaction, an obvious effect was similar to that on fruit peel thickness in the first and second seasons. Manfalouty cultivar exhibited higher significant values in fruit peel thickness during both seasons.

Concerning aril weight $\%$, Wardy $\mathrm{cv}$. was better in this concern during both seasons. Regarding the interaction, Wardy cv. under all treatments especially the control, recorded the highest values ( $1^{\text {st }}$ season). Similar results were confirmed by Amit et al. (2014) who reported that the concentration of most micronutrients was greater in the arils than in the peel especially in early season. The relative order of concentration of micronutrients in arils was $\mathrm{B}>\mathrm{Fe}>\mathrm{Zn}>\mathrm{Cu}>\mathrm{Mn}$.

Data in Table (6) also indicate that the control treatment achieved the highest values of No. of arils/fruit in the first and second seasons. Concerning the interaction of the two factors, Wardy cultivar under the control surpassed other treatments during both seasons. As for cultivar effect, Wardy was superior in this concern in both seasons.

Guneri et al. (2016) reported that Ca treatments significantly increased peel percentage in pomegranate fruits. Also, Yadav et al. (2014) declared that, the application of zinc sulphate + $0.4 \%$ boric acid was found significantly superior

Table (6): Effect of some nutrient applications on fruit peel thickness (cm), aril weight (\%) and No. of arils/fruit of Wardy and Manfalouty pomegranate trees during 2013 and 2014 seasons.

\begin{tabular}{|c|c|c|c|c|c|c|c|c|c|c|}
\hline \multirow[b]{2}{*}{ No. } & \multirow[b]{2}{*}{ Treatments } & \multicolumn{3}{|c|}{ Fruit peel thickness $(\mathrm{cm})$} & \multicolumn{3}{|c|}{ Aril weight (\%) } & \multicolumn{3}{|c|}{ No. of arils/fruit } \\
\hline & & \begin{tabular}{|c|}
$\begin{array}{c}\text { Wardy } \\
\text { cv. }\end{array}$ \\
\end{tabular} & $\begin{array}{l}\text { ***Man. } \\
\text { cv. }\end{array}$ & Mean (B) & $\begin{array}{c}\text { Wardy } \\
\text { cv. }\end{array}$ & $\begin{array}{l}\text { ***Man. } \\
\text { cv. }\end{array}$ & $\begin{array}{c}\text { Mean } \\
\text { (B) }\end{array}$ & \begin{tabular}{|c|}
$\begin{array}{c}\text { Wardy } \\
\text { cv. }\end{array}$ \\
\end{tabular} & $\begin{array}{c}* * \text { Man. } \\
\text { cv. }\end{array}$ & \begin{tabular}{|c|}
$\begin{array}{c}\text { Mean } \\
(\text { B })\end{array}$ \\
\end{tabular} \\
\hline & & \multicolumn{9}{|c|}{ First season: 2013} \\
\hline T1 & Control (farm fertilization) & $0.55 \mathrm{c}$ & $0.62 \mathrm{ab}$ & $0.59 \mathrm{~B}$ & $60.00 \mathrm{a}$ & $56.00 \mathrm{c}$ & $58.00 \mathrm{~A}$ & $255.5 \mathrm{a}$ & $239.3 \mathrm{~d}$ & $247.4 \mathrm{~A}$ \\
\hline $\mathbf{T 2}$ & Foliar spraying with $\mathrm{ZnSO}_{4}(0.3 \%)$ & $0.58 \mathrm{bc}$ & $0.65 \mathrm{a}$ & $0.62 \mathrm{AB}$ & $58.50 \mathrm{ab}$ & $54.60 \mathrm{~cd}$ & $56.55 \mathrm{~B}$ & $252.0 \mathrm{~b}$ & $235.0 \mathrm{e}$ & 243.5 B \\
\hline $\mathbf{T 3}$ & $\begin{array}{l}\text { Foliar spraying with *mix. of } \\
\text { micronutrients at } 2 \mathrm{~g} / \mathrm{l}\end{array}$ & $0.59 \mathrm{bc}$ & $0.65 \mathrm{a}$ & $0.62 \mathrm{AB}$ & $58.40 \mathrm{ab}$ & $54.50 \mathrm{~cd}$ & 56.45 B & $250.0 \mathrm{bc}$ & $233.0 \mathrm{e}$ & $241.5 \mathrm{C}$ \\
\hline T4 & Soil application of $\mathrm{CaSO}_{4}$ at $500 \mathrm{~g} /$ tree & $.59 \mathrm{bc}$ & $0.66 \mathrm{a}$ & $0.62 \mathrm{AB}$ & $58.20 \mathrm{~b}$ & $54.40 \mathrm{~cd}$ & $56.30 \mathrm{~B}$ & $250.0 \mathrm{bc}$ & $233.0 \mathrm{e}$ & $241.50 \mathrm{C}$ \\
\hline T5 & $\begin{array}{l}\text { Foliar spraying with } \mathrm{ZnSO}_{4}(0.3 \%)+ \\
\text { mix. of micronutrients at } 2 \mathrm{~g} / \mathrm{l}\end{array}$ & $0.59 \mathrm{bc}$ & $0.66 \mathrm{a}$ & $0.62 \mathrm{AB}$ & $58.10 \mathrm{~b}$ & $54.30 \mathrm{~cd}$ & $56.20 \mathrm{~B}$ & $249.0 \mathrm{c}$ & $233.0 \mathrm{e}$ & 241.0 C \\
\hline T6 & \begin{tabular}{|l|} 
Soil application of $\mathrm{CaSO}_{4}$ at $500 \mathrm{~g} /$ tree \\
+ foliar spraying with $\mathrm{ZnSO}_{4}(0.3 \%)$ \\
\end{tabular} & $0.59 \mathrm{bc}$ & $0.66 \mathrm{a}$ & $0.62 \mathrm{AB}$ & $58.00 \mathrm{~b}$ & $54.20 \mathrm{~d}$ & $56.10 \mathrm{~B}$ & $249.0 \mathrm{c}$ & $233.0 \mathrm{e}$ & $241.0 \mathrm{C}$ \\
\hline T7 & $\begin{array}{l}\text { Soil application of } \mathrm{CaSO}_{4} \text { at } 500 \mathrm{~g} / \text { tree } \\
+ \text { foliar spraying with mix. of } \\
\text { micronutrients at } 2 \mathrm{~g} / \mathrm{l}\end{array}$ & $0.59 \mathrm{bc}$ & $0.66 \mathrm{a}$ & $0.62 \mathrm{AB}$ & $58.00 \mathrm{~b}$ & $54.00 \mathrm{~d}$ & 56.00 B & $250.0 \mathrm{bc}$ & $233.0 \mathrm{e}$ & $241.50 \mathrm{C}$ \\
\hline T8 & $\begin{array}{l}\text { Soil application } \mathrm{CaSO}_{4} \text { at } 500 \mathrm{~g} / \text { tree + } \\
\text { foliar spraying } \mathrm{ZnSO}_{4}(0.3 \%)+\text { mix. } \\
\text { of micronutrients at } 2 \mathrm{~g} / \mathrm{l}\end{array}$ & $0.60 \mathrm{a}-\mathrm{c}$ & $0.66 \mathrm{a}$ & $0.63 \mathrm{~A}$ & $58.00 \mathrm{~b}$ & $54.00 \mathrm{~d}$ & $56.00 \mathrm{~B}$ & $250.0 \mathrm{bc}$ & $233.0 \mathrm{e}$ & $241.50 \mathrm{C}$ \\
\hline \multicolumn{2}{|r|}{ Mean (A) } & $0.59 \mathrm{~B}$ & 0.65 A & & $58.40 \mathrm{~A}$ & $54.50 B$ & & $247.0 \mathrm{~A}$ & 234.0 B & \\
\hline \multicolumn{11}{|c|}{ Second season: 2014} \\
\hline T1 & Control (farm fertilization) & $0.56 \mathrm{c}$ & $0.65 \mathrm{ab}$ & $0.61 \mathrm{~B}$ & $60.70 \mathrm{a}$ & $59.00 \mathrm{~b}$ & $59.85 \mathrm{~A}$ & $256.0 \mathrm{a}$ & $240.0 \mathrm{c}$ & 248.0 A \\
\hline $\mathbf{T 2}$ & Foliar spraying with $\mathrm{ZnSO}_{4}(0.3 \%)$ & $0.59 \mathrm{bc}$ & $0.69 \mathrm{a}$ & $0.64 \mathrm{AB}$ & $59.00 \mathrm{~b}$ & $58.00 \mathrm{~b}$ & 58.50 B & $250.0 \mathrm{~b}$ & $233.0 \mathrm{~d}$ & 241.5 B \\
\hline T3 & $\begin{array}{l}\text { Foliar spraying with } \\
\text { micronutrients at } 2 \text { g/l }\end{array}$ & $0.60 \mathrm{bc}$ & $0.70 \mathrm{a}$ & $0.65 \mathrm{~A}$ & $59.00 \mathrm{~b}$ & $58.00 \mathrm{~b}$ & 58.50 B & $249.0 \mathrm{~b}$ & $232.0 \mathrm{~d}$ & 240.5 BC \\
\hline T4 & $\begin{array}{l}\text { Soil application of } \mathrm{CaSO}_{4} \text { at } 500 \\
\text { g/tree }\end{array}$ & $0.60 \mathrm{bc}$ & $0.70 \mathrm{a}$ & $0.65 \mathrm{~A}$ & $58.90 \mathrm{~b}$ & $58.00 \mathrm{~b}$ & 58.45 B & $249.0 \mathrm{~b}$ & $232.0 \mathrm{~d}$ & 240.5 BC \\
\hline T5 & $\begin{array}{l}\text { Foliar spraying with } \mathrm{ZnSO}_{4}(0.3 \%) \\
+ \text { mix. of micronutrients at } 2 \mathrm{~g} / \mathrm{l} \\
\end{array}$ & $0.60 \mathrm{bc}$ & $0.70 \mathrm{a}$ & $0.65 \mathrm{~A}$ & $58.90 \mathrm{~b}$ & $58.00 \mathrm{~b}$ & 58.40 B & $249.0 \mathrm{~b}$ & $231.0 \mathrm{~d}$ & $240.0 \mathrm{C}$ \\
\hline T6 & $\begin{array}{l}\text { Soil application of } \mathrm{CaSO}_{4} \text { at } 500 \\
\text { g/tree + foliar spraying with } \mathrm{ZnSO}_{4} \\
(0.3 \%)\end{array}$ & $0.60 \mathrm{bc}$ & $0.70 \mathrm{a}$ & $0.65 \mathrm{~A}$ & $58.80 \mathrm{~b}$ & $58.00 \mathrm{~b}$ & 58.40 B & $249.0 \mathrm{~b}$ & $231.0 \mathrm{~d}$ & $240.0 \mathrm{C}$ \\
\hline T7 & $\begin{array}{l}\text { Soil application of } \mathrm{CaSO}_{4} \text { at } 500 \\
\text { g/tree + foliar spraying with mix. of } \\
\text { micronutrients at } 2 \mathrm{~g} / \mathrm{l}\end{array}$ & $0.60 \mathrm{bc}$ & $0.70 \mathrm{a}$ & $0.65 \mathrm{~A}$ & $58.80 \mathrm{~b}$ & $58.00 \mathrm{~b}$ & 58.40 B & $249.0 \mathrm{~b}$ & $231.0 \mathrm{~d}$ & $240.0 \mathrm{C}$ \\
\hline T8 & $\begin{array}{l}\text { Soil application } \mathrm{CaSO}_{4} \text { at } 500 \mathrm{~g} / \text { tree } \\
+ \text { foliar spraying } \mathrm{ZnSO}_{4}(0.3 \%)+ \\
\text { mix. of micronutrients at } 2 \mathrm{~g} / 1\end{array}$ & $0.60 \mathrm{bc}$ & $0.70 \mathrm{a}$ & $0.65 \mathrm{~A}$ & $58.70 \mathrm{~b}$ & $58.00 \mathrm{~b}$ & 58.35 B & $249.0 \mathrm{~b}$ & $231.0 \mathrm{~d}$ & $240.0 \mathrm{C}$ \\
\hline & Mean (A) & 0.59 B & 0.69 A & & $59.09 \mathrm{~A}$ & 58.13 B & & $250.0 \mathrm{~A}$ & 232.6 B & \\
\hline
\end{tabular}

Means followed by the same letter in a column or row do not differ significantly according to Duncan's New

Multiple Range Test at $\mathrm{P}=0.05$

$*$ mix. of micronutrients $=(\mathrm{Mg}+\mathrm{Fe}+\mathrm{Zn}+\mathrm{Mn}+\mathrm{Cu}+\mathrm{B}+\mathrm{Mo}+\mathrm{S}) \quad * *$ Man. $=$ Manfalouty cultivar

(A) $=$ Cultivars $(\mathrm{B})=$ Nutrient applications 
with respect to increase in the number of arils per fruit. In addition Hamouda et al. (2015) revealed that applied of foliar nutrient spraying led to significant increases in pomegranate fruit physical properties as well as fruit quality as compared with unsprayed treatment.

\subsection{Fruit chemical properties}

\subsubsection{T.S.S (\%), Acidity (\%) and T.S.S/acidity}

Data in Table (7) indicate that the differences among the treatments were highly significant. Total soluble solids (\%) values ranged from $13.50 \& 13.20 \%$ (control) to reach $16.80 \&$ $16.50 \%$ (soil application of CaSO4 at $500 \mathrm{~g} /$ tree + foliar spraying $\mathrm{ZnSO}_{4}$ at $0.3 \%+$ spraying mix. of micronutrients at $2 \mathrm{~g} / \mathrm{l}$ ) in the two seasons.

According to the interaction effect, the previously mentioned treatment with Manfalouty cultivar showed the extremist values during the two growing seasons. In regards to the cultivars, Manfalouty was better in both seasons. Regarding to acidity, the highest acidity was obtained by the control treatment in both seasons. In addition, the interaction between treatments and cultivars, the highest values were recorded by the untreated Manfalouty trees followed by in a descending order when sprayed with $\mathrm{ZnSO}_{4}$ at $0.3 \%$ in both seasons.

Table (7): Effect of some nutrient applications on TSS, acidity and TSS/acid ratio of Wardy and Manfalouty pomegranate trees during 2013 and 2014 seasons.

\begin{tabular}{|c|c|c|c|c|c|c|c|c|c|c|}
\hline \multirow[b]{2}{*}{ No. } & \multirow[b]{2}{*}{ Treatments } & \multicolumn{3}{|c|}{ T.S.S (\%) } & \multicolumn{3}{|c|}{ Acidity (\%) } & \multicolumn{3}{|c|}{ TSS/acidity ratio } \\
\hline & & $\begin{array}{c}\text { Wardy } \\
\text { cv. }\end{array}$ & \begin{tabular}{|c|}
$* *$ Man. \\
cv.
\end{tabular} & Mean (B) & \begin{tabular}{|c|}
$\begin{array}{c}\text { Wardy } \\
\text { cv. }\end{array}$ \\
\end{tabular} & $\begin{array}{c}* * \text { Man. } \\
\text { cv. }\end{array}$ & $\begin{array}{c}\text { Mean } \\
(B)\end{array}$ & \begin{tabular}{|c|}
$\begin{array}{c}\text { Wardy } \\
\text { cv. }\end{array}$ \\
\end{tabular} & $\begin{array}{c}\text { ***Man. } \\
\text { cv. }\end{array}$ & Mean (B) \\
\hline & & \multicolumn{9}{|c|}{ First season: 2013} \\
\hline T1 & Control (farm fertilization) & $13.20 \mathrm{~h}$ & $13.80 \mathrm{~g}$ & $13.50 \mathrm{G}$ & $1.10 \mathrm{~g}$ & $1.47 \mathrm{a}$ & $1.29 \mathrm{~A}$ & $12.00 \mathrm{~h}$ & $9.38 \mathrm{~m}$ & $10.69 \mathrm{H}$ \\
\hline T2 & Foliar spraying with $\mathrm{ZnSO}_{4}(0.3 \%)$ & $13.80 \mathrm{~g}$ & $14.40 \mathrm{f}$ & $14.10 \mathrm{~F}$ & $1.09 \mathrm{~g}$ & $1.45 \mathrm{ab}$ & $1.27 \mathrm{AB}$ & $12.72 \mathrm{fg}$ & $9.93 \mathrm{~lm}$ & $11.12 \mathrm{G}$ \\
\hline T3 & $\begin{array}{l}\text { Foliar spraying with } * \text { mix. of } \\
\text { micronutrients at } 2 \mathrm{~g} / \mathrm{l}\end{array}$ & $14.80 \mathrm{ef}$ & $15.40 \mathrm{~d}$ & $15.10 \mathrm{D}$ & $1.03 \mathrm{hi}$ & $1.41 \mathrm{~b}-\mathrm{d}$ & $1.22 \mathrm{CD}$ & $14.37 \mathrm{~d}$ & $10.92 \mathrm{jk}$ & $12.65 \mathrm{~F}$ \\
\hline T4 & $\begin{array}{l}\text { Soil application of } \mathrm{CaSO}_{4} \text { at } 500 \\
\text { g/tree }\end{array}$ & $14.30 \mathrm{fg}$ & 14.80 ef & $14.55 \mathrm{E}$ & $1.06 \mathrm{gh}$ & $1.43 \mathrm{a}-\mathrm{c}$ & $1.25 \mathrm{BC}$ & $13.49 \mathrm{e}$ & $10.35 \mathrm{kl}$ & $11.92 \mathrm{~F}$ \\
\hline T5 & $\begin{array}{l}\text { Foliar spraying with } \mathrm{ZnSO}_{4}(0.3 \%) \\
+ \text { mix. of micronutrients at } 2 \mathrm{~g} / \mathrm{l}\end{array}$ & $15.20 \mathrm{de}$ & $15.70 \mathrm{~cd}$ & $15.45 \mathrm{D}$ & $1.02 \mathrm{hi}$ & $1.39 \mathrm{c}-\mathrm{e}$ & $1.21 \mathrm{DE}$ & $14.98 \mathrm{~d}$ & $11.29 \mathrm{ij}$ & 13.14 D \\
\hline T6 & $\begin{array}{l}\text { Soil application of } \mathrm{CaSO}_{4} \text { at } \mathbf{5 0 0} \\
\text { g/tree + foliar spraying with } \mathrm{ZnSO}_{4} \\
(0.3 \%)\end{array}$ & $15.70 \mathrm{~cd}$ & $16.30 \mathrm{~b}$ & $16.00 \mathrm{C}$ & $1.00 \mathrm{ij}$ & $1.37 \mathrm{~d}-\mathrm{f}$ & $1.19 \mathrm{DE}$ & $15.70 \mathrm{c}$ & $11.90 \mathrm{hi}$ & $13.80 \mathrm{C}$ \\
\hline T7 & $\begin{array}{l}\text { Soil application of } \mathrm{CaSO}_{4} \text { at } 500 \\
\text { g/tree + foliar spraying with mix. of } \\
\text { micronutrients at } 2 \mathrm{~g} / \mathrm{l}\end{array}$ & $16.10 \mathrm{bc}$ & $16.70 \mathrm{ab}$ & $16.40 \mathrm{~B}$ & $0.99 \mathrm{ij}$ & $1.35 \mathrm{ef}$ & $1.17 \mathrm{EF}$ & $16.35 \mathrm{~b}$ & $12.37 \mathrm{gh}$ & $14.36 \mathrm{~B}$ \\
\hline T8 & $\begin{array}{l}\text { Soil application } \mathrm{CaSO}_{4} \text { at } 500 \mathrm{~g} / \text { tree } \\
+ \text { foliar spraying } \mathrm{ZnSO}_{4}(0.3 \%)+ \\
\text { mix. of micronutrients at } 2 \mathrm{~g} / \mathrm{l}\end{array}$ & $16.40 \mathrm{~b}$ & $17.20 \mathrm{a}$ & $16.80 \mathrm{~A}$ & $0.96 \mathrm{j}$ & $1.32 \mathrm{f}$ & $1.14 \mathrm{~F}$ & $17.08 \mathrm{a}$ & $13.03 \mathrm{ef}$ & $15.06 \mathrm{~A}$ \\
\hline \multicolumn{2}{|r|}{ Mean (A) } & $14.94 \mathrm{~B}$ & $15.54 \mathrm{~A}$ & & $1.03 \mathrm{~B}$ & $1.39 \mathrm{~A}$ & & $14.59 \mathrm{~A}$ & $11.15 \mathrm{~B}$ & \\
\hline & & \multicolumn{9}{|c|}{ Second season: 2014} \\
\hline T1 & Control (farm fertilization) & $12.90 \mathrm{~h}$ & $13.50 \mathrm{gh}$ & $13.20 \mathrm{~F}$ & $1.05 \mathrm{e}$ & $1.46 \mathrm{a}$ & $1.26 \mathrm{~A}$ & $12.29 \mathrm{hi}$ & $9.25 \mathrm{~m}$ & $10.77 \mathrm{H}$ \\
\hline $\mathbf{T 2}$ & Foliar spraying with $\mathrm{ZnSO}_{4}(0.3 \%)$ & $13.50 \mathrm{gh}$ & $14.00 \mathrm{fg}$ & $13.75 \mathrm{E}$ & $1.04 \mathrm{ef}$ & $1.44 \mathrm{ab}$ & $1.24 \mathrm{~A}$ & $13.04 \mathrm{~g}$ & $9.721 \mathrm{~m}$ & $11.38 \mathrm{G}$ \\
\hline T3 & $\begin{array}{l}\text { Foliar spraying with } * \text { mix. of } \\
\text { micronutrients at } 2 \text { g/l }\end{array}$ & $14.50 \mathrm{ef}$ & $15.00 \mathrm{de}$ & $14.75 \mathrm{C}$ & $1.00 \mathrm{e}-\mathrm{g}$ & $1.40 \mathrm{a}-\mathrm{d}$ & $1.20 \mathrm{~A}-\mathrm{C}$ & $14.44 \mathrm{e}$ & $10.71 \mathrm{jk}$ & $12.57 \mathrm{E}$ \\
\hline T4 & $\begin{array}{l}\text { Soil application of } \mathrm{CaSO}_{4} \text { at } 500 \\
\text { g/tree }\end{array}$ & $14.00 \mathrm{fg}$ & 14.50 ef & $14.25 \mathrm{D}$ & $1.02 \mathrm{e}-\mathrm{g}$ & $1.42 \mathrm{a}-\mathrm{c}$ & $1.22 \mathrm{AB}$ & $13.73 \mathrm{f}$ & $10.21 \mathrm{kl}$ & $11.97 \mathrm{~F}$ \\
\hline T5 & $\begin{array}{l}\text { Foliar spraying with } \mathrm{ZnSO}_{4}(0.3 \%) \\
+ \text { mix. of micronutrients at } 2 \mathrm{~g} / \mathrm{l} \\
\end{array}$ & $14.90 \mathrm{de}$ & $15.40 \mathrm{~cd}$ & $15.15 \mathrm{C}$ & $0.98 \mathrm{e}-\mathrm{h}$ & $1.38 \mathrm{a}-\mathrm{d}$ & $1.18 \mathrm{~B}-\mathrm{D}$ & $15.20 \mathrm{~d}$ & $11.16 \mathrm{j}$ & 13.18 D \\
\hline T6 & $\begin{array}{l}\text { Soil application of } \mathrm{CaSO}_{4} \text { at } 500 \\
\text { g/tree + foliar spraying with } \mathrm{ZnSO}_{4} \\
(0.3 \%)\end{array}$ & $15.40 \mathrm{~cd}$ & $16.00 \mathrm{bc}$ & $15.70 \mathrm{~B}$ & $0.96 \mathrm{f}-\mathrm{h}$ & $1.36 \mathrm{~b}-\mathrm{d}$ & $1.16 \mathrm{C}-\mathrm{E}$ & $16.04 \mathrm{c}$ & $11.76 \mathrm{i}$ & $13.90 \mathrm{C}$ \\
\hline T7 & $\begin{array}{l}\text { Soil application of } \mathrm{CaSO}_{4} \text { at } 500 \\
\text { g/tree + foliar spraying with mix. of } \\
\text { micronutrients at } 2 \mathrm{~g} / \mathrm{l}\end{array}$ & $15.80 \mathrm{bc}$ & $16.40 \mathrm{ab}$ & $16.10 \mathrm{AB}$ & $0.94 \mathrm{gh}$ & $1.34 \mathrm{~cd}$ & 1.14 DE & $16.81 \mathrm{~b}$ & $12.24 \mathrm{hi}$ & 14.52 B \\
\hline T8 & $\begin{array}{l}\text { Soil application } \mathrm{CaSO}_{4} \text { at } 500 \mathrm{~g} / \text { tree } \\
+ \text { foliar spraying } \mathrm{ZnSO}_{4}(0.3 \%)+ \\
\text { mix. of micronutrients at } 2 \mathrm{~g} / 1 \\
\end{array}$ & $16.20 \mathrm{ab}$ & $16.80 \mathrm{a}$ & $16.50 \mathrm{~A}$ & $0.91 \mathrm{~h}$ & $1.32 \mathrm{~d}$ & $1.12 \mathrm{E}$ & $17.72 \mathrm{a}$ & $12.75 \mathrm{gh}$ & $15.23 \mathrm{~A}$ \\
\hline & Mean (A) & $14.65 \mathrm{~B}$ & $15.20 \mathrm{~A}$ & & 0.99 B & $1.39 \mathrm{~A}$ & & $14.91 \mathrm{~A}$ & $10.98 \mathrm{~B}$ & \\
\hline
\end{tabular}

Means followed by the same letter in a column or row do not differ significantly according to Duncan's New

Multiple Range Test at $\mathrm{P}=0.05$

$*$ mix. of micronutrients $=(\mathrm{Mg}+\mathrm{Fe}+\mathrm{Zn}+\mathrm{Mn}+\mathrm{Cu}+\mathrm{B}+\mathrm{Mo}+\mathrm{S}) \quad * *$ Man. $=$ Manfalouty cultivar

$(\mathrm{A})=$ Cultivars $(\mathrm{B})=$ Nutrient applications 
Concerning the cultivars under study, Manfalouty was the superior cv. in both seasons. Concerning T.S.S./acidity ratio, the highest values were obtained by soil application of $\mathrm{CaSO}_{4}$ at $500 \mathrm{~g} /$ tree + foliar spraying mix. of micronutrients at $2 \mathrm{~g} / 1$ with or without foliar spraying $\mathrm{ZnSO}_{4}$ at $0.3 \%$. The same previously two treatments recorded the highest values of T.S.S./acidity ratio when applied to Wardy cv. According to pomegranate cultivar, Wardy cv. gave the higher values in both seasons.

Sharma and Belsare (2009) and Pande et al., (2012) reported that, foliar application, of zinc and boron in combination was the most effective in increasing tritable acidity, TSS and TSS/acid ratio in pomegranate. This may be due to an increase in the concentration of sugars in fruits of plants supplemented with boron which might be the result of an increase in translocation of sugar Pande et al., 2012).

\subsubsection{Total sugars, reducing sugars and total soluble tannins (\%)}

As for the effect of the tested treatments, data presented in Table (8) reveal that, the highest records of the total and reducing sugars (\%) were obtained by the trees subjected to soil application of $\mathrm{CaSO} 4$ at $500 \mathrm{~g} /$ tree + spraying mix. of micronutrients at $2 \mathrm{~g} / \mathrm{l}$ either with or without spraying $\mathrm{ZnSO}_{4}$ at $0.3 \%$ in the two seasons. After the interaction between treatments and cultivars, $\mathrm{CaSO}_{4}$ as $500 \mathrm{~g} / \mathrm{tree}+\mathrm{ZnSO}_{4}$ at $(0.3 \%)+$ mix. of micronutrients at $2 \mathrm{~g} / 1$ with Manfalouty cultivar surpassed the others for both mentioned parameters in both seasons. Manfalouty cultivar had higher values in the total and reducing sugars (\%) in both seasons.

Table (8): Effect of some nutrient applications on the percentages of total sugars, reducing sugars and total soluble tannins of Wardy and Manfalouty pomegranate trees during 2013 and 2014 seasons.

\begin{tabular}{|c|c|c|c|c|c|c|c|c|c|c|}
\hline \multirow[b]{2}{*}{ No. } & \multirow[b]{2}{*}{ Treatments } & \multicolumn{3}{|c|}{ Total sugars (\%) } & \multicolumn{3}{|c|}{ Reducing sugars $(\%)$} & \multicolumn{3}{|c|}{ Total soluble tannins $(\%)$} \\
\hline & & \begin{tabular}{|c|} 
Wardy \\
cv.
\end{tabular} & \begin{tabular}{|c|}
$* *$ Man. \\
cv.
\end{tabular} & Mean (B) & $\begin{array}{c}\text { Wardy } \\
\text { cv. }\end{array}$ & $\begin{array}{c}* * \text { Man. } \\
\text { cv. }\end{array}$ & Mean (B) & $\begin{array}{c}\text { Wardy } \\
\text { cv. }\end{array}$ & $\begin{array}{c}* * \text { Man. } \\
\text { cv. }\end{array}$ & $\begin{array}{c}\text { Mean } \\
\text { (B) }\end{array}$ \\
\hline & & \multicolumn{9}{|c|}{ First season: 2013} \\
\hline T1 & Control (farm fertilization) & $11.00 \mathrm{k}$ & $11.90 \mathrm{~h}-\mathrm{j}$ & $11.45 \mathrm{~F}$ & $10.00 \mathrm{j}$ & $10.90 \mathrm{gh}$ & $10.45 \mathrm{G}$ & $1.11 \mathrm{ef}$ & $1.29 \mathrm{a}$ & $1.20 \mathrm{~A}$ \\
\hline $\mathbf{T 2}$ & Foliar spraying with $\mathrm{ZnSO}_{4}(0.3 \%)$ & $11.40 \mathrm{jk}$ & $12.50 \mathrm{f}-\mathrm{h}$ & $11.95 \mathrm{E}$ & $10.30 \mathrm{ij}$ & $11.20 \mathrm{fg}$ & 10.75 FG & $1.07 \mathrm{fg}$ & $1.26 \mathrm{ab}$ & $1.17 \mathrm{AB}$ \\
\hline T3 & $\begin{array}{l}\text { Foliar spraying with *mix. of } \\
\text { micronutrients at } 2 \mathrm{~g} / \mathrm{l}\end{array}$ & $12.20 \mathrm{~g}-\mathrm{i}$ & $13.40 \mathrm{de}$ & 12.80 D & $10.90 \mathrm{gh}$ & $11.80 \mathrm{de}$ & 11.35 DE & $1.00 \mathrm{hi}$ & $1.21 \mathrm{bc}$ & $1.10 \mathrm{C}$ \\
\hline T4 & Soil application of $\mathrm{CaSO}_{4}$ at $500 \mathrm{~g} /$ tree & $11.80 \mathrm{ij}$ & $12.90 \mathrm{ef}$ & $12.35 \mathrm{E}$ & $10.60 \mathrm{hi}$ & $11.50 \mathrm{ef}$ & 11.05 EF & $1.04 \mathrm{gh}$ & $1.23 \mathrm{~b}$ & $1.14 \mathrm{BC}$ \\
\hline T5 & $\begin{array}{l}\text { Foliar spraying with } \mathrm{ZnSO}_{4}(0.3 \%)+ \\
\text { mix. of micronutrients at } 2 \mathrm{~g} / \mathrm{l}\end{array}$ & $12.60 \mathrm{fg}$ & $13.80 \mathrm{~cd}$ & 13.20 CD & $11.20 \mathrm{fg}$ & $12.10 \mathrm{~cd}$ & 11.65 CD & $0.96 \mathrm{ij}$ & $1.17 \mathrm{~cd}$ & $1.07 \mathrm{D}$ \\
\hline T6 & $\begin{array}{l}\text { Soil application of } \mathrm{CaSO}_{4} \text { at } 500 \mathrm{~g} / \text { tree + } \\
\text { foliar spraying with } \mathrm{ZnSO}_{4}(0.3 \%)\end{array}$ & 1300 ef & $14.20 \mathrm{bc}$ & $13.60 \mathrm{C}$ & $11.50 \mathrm{ef}$ & $12.40 \mathrm{bc}$ & $11.95 \mathrm{BC}$ & $0.92 \mathrm{jk}$ & $1.14 \mathrm{de}$ & 1.03 DE \\
\hline T7 & $\begin{array}{l}\text { Soil application of } \mathrm{CaSO}_{4} \text { at } 500 \mathrm{~g} / \mathrm{tree}+ \\
\text { foliar spraying with mix. of } \\
\text { micronutrients at } 2 \mathrm{~g} / \mathrm{l}\end{array}$ & $13.40 \mathrm{de}$ & $14.70 \mathrm{ab}$ & 14.05 B & $11.80 \mathrm{de}$ & $12.70 \mathrm{ab}$ & $12.25 \mathrm{AB}$ & $0.88 \mathrm{kl}$ & $1.12 \mathrm{~d}-\mathrm{f}$ & $1.00 \mathrm{EF}$ \\
\hline T8 & $\begin{array}{l}\text { Soil application } \mathrm{CaSO}_{4} \text { at } 500 \mathrm{~g} / \mathrm{tree}+ \\
\text { foliar spraying } \mathrm{ZnSO}_{4}(0.3 \%)+\text { mix. of } \\
\text { micronutrients at } 2 \mathrm{~g} / \mathrm{l}\end{array}$ & $13.80 \mathrm{~cd}$ & $15.20 \mathrm{a}$ & $14.50 \mathrm{~A}$ & $12.10 \mathrm{~cd}$ & $13.00 \mathrm{a}$ & $12.55 \mathrm{~A}$ & 0.831 & $1.10 \mathrm{ef}$ & $0.97 \mathrm{~F}$ \\
\hline \multicolumn{2}{|r|}{ Mean (A) } & $12.40 \mathrm{~B}$ & $13.57 \mathrm{~A}$ & & 11.05B & $11.95 \mathrm{~A}$ & & $0.98 \mathrm{~B}$ & $1.19 \mathrm{~A}$ & \\
\hline & & \multicolumn{9}{|c|}{ Second season: 2014} \\
\hline T1 & Control (farm fertilization) & $10.70 \mathrm{j}$ & $11.60 \mathrm{hi}$ & $11.15 \mathrm{~h}$ & $9.90 \mathrm{j}$ & $10.80 \mathrm{gh}$ & $10.35 \mathrm{E}$ & $1.16 \mathrm{~d}-\mathrm{f}$ & $1.36 \mathrm{a}$ & $1.26 \mathrm{~A}$ \\
\hline $\mathbf{T 2}$ & Foliar spraying with $\mathrm{ZnSO}_{4}(0.3 \%)$ & $11.10 \mathrm{ij}$ & $12.20 \mathrm{fg}$ & $11.65 \mathrm{~g}$ & $10.20 \mathrm{ij}$ & $11.10 \mathrm{fg}$ & $10.65 \mathrm{DE}$ & $1.12 \mathrm{ef}$ & $1.30 \mathrm{ab}$ & $1.21 \mathrm{AB}$ \\
\hline T3 & $\begin{array}{l}\text { Foliar spraying with *mix. of } \\
\text { micronutrients at } 2 \mathrm{~g} / \mathrm{l}\end{array}$ & $11.90 \mathrm{gh}$ & $13.10 \mathrm{de}$ & $12.50 \mathrm{e}$ & $10.80 \mathrm{gh}$ & $11.80 \mathrm{de}$ & $11.30 \mathrm{C}$ & $1.04 \mathrm{gh}$ & $1.25 \mathrm{bc}$ & $1.15 \mathrm{CD}$ \\
\hline $\mathbf{T 4}$ & Soil application of $\mathrm{CaSO}_{4}$ at $500 \mathrm{~g} /$ tree & $11.50 \mathrm{hi}$ & $12.60 \mathrm{ef}$ & $12.05 \mathrm{f}$ & $10.50 \mathrm{hi}$ & $11.40 \mathrm{ef}$ & $10.95 \mathrm{D}$ & $1.09 \mathrm{fg}$ & $1.27 \mathrm{~b}$ & $1.18 \mathrm{BC}$ \\
\hline T5 & $\begin{array}{l}\text { Foliar spraying with } \mathrm{ZnSO}_{4}(0.3 \%)+ \\
\text { mix. of micronutrients at } 2 \mathrm{~g} / \mathrm{l}\end{array}$ & $12.30 \mathrm{fg}$ & $13.50 \mathrm{~cd}$ & $12.90 \mathrm{~d}$ & $11.10 \mathrm{fg}$ & $12.10 \mathrm{~cd}$ & $11.60 \mathrm{BC}$ & $1.01 \mathrm{hi}$ & $1.22 \mathrm{~b}-\mathrm{d}$ & $1.12 \mathrm{D}$ \\
\hline T6 & $\begin{array}{l}\text { Soil application of } \mathrm{CaSO}_{4} \text { at } 500 \mathrm{~g} / \text { tree + } \\
\text { foliar spraying with } \mathrm{ZnSO}_{4}(0.3 \%)\end{array}$ & $12.70 \mathrm{ef}$ & $13.90 \mathrm{bc}$ & $13.30 \mathrm{c}$ & $11.40 \mathrm{ef}$ & $12.40 \mathrm{bc}$ & $11.90 \mathrm{~B}$ & $0.94 \mathrm{i}$ & $1.18 \mathrm{c}-\mathrm{e}$ & $1.06 \mathrm{E}$ \\
\hline T7 & $\begin{array}{l}\text { Soil application of } \mathrm{CaSO}_{4} \text { at } 500 \mathrm{~g} / \text { tree }+ \\
\text { foliar spraying with mix. of } \\
\text { micronutrients at } 2 \mathrm{~g} / \mathrm{l}\end{array}$ & $13.10 \mathrm{de}$ & $14.30 \mathrm{~b}$ & $13.70 \mathrm{~b}$ & $11.70 \mathrm{de}$ & $12.80 \mathrm{ab}$ & $12.25 \mathrm{~A}$ & $0.93 \mathrm{ij}$ & $1.15 \mathrm{~d}-\mathrm{f}$ & $1.04 \mathrm{EF}$ \\
\hline T8 & $\begin{array}{l}\text { Soil application } \mathrm{CaSO}_{4} \text { at } 500 \mathrm{~g} / \mathrm{tree}+ \\
\text { foliar spraying } \mathrm{ZnSO}_{4}(0.3 \%)+\text { mix. of } \\
\text { micronutrients at } 2 \mathrm{~g} / \mathrm{l}\end{array}$ & $13.50 \mathrm{~cd}$ & $14.90 \mathrm{a}$ & $14.20 \mathrm{a}$ & $12.00 \mathrm{~cd}$ & $13.10 \mathrm{a}$ & $12.55 \mathrm{~A}$ & $0.86 \mathrm{j}$ & $1.13 \mathrm{ef}$ & $1.00 \mathrm{~F}$ \\
\hline & Mean (A) & $12.10 \mathrm{~B}$ & $13.26 \mathrm{~A}$ & & $10.95 \mathrm{~B}$ & $11.94 \mathrm{~A}$ & & $1.02 \mathrm{~B}$ & $1.23 \mathrm{~A}$ & \\
\hline
\end{tabular}

Means followed by the same letter in a column or row do not differ significantly according to Duncan's New

Multiple Range Test at $\mathrm{P}=0.05----*$ mix. of micronutrients $=(\mathrm{Mg}+\mathrm{Fe}+\mathrm{Zn}+\mathrm{Mn}+\mathrm{Cu}+\mathrm{B}+\mathrm{Mo}+\mathrm{S})$

**Man. = Manfalouty cultivar--------(A) = Cultivars $(\mathrm{B})=$ Nutrient applications 
Concerning the total soluble tannins (\%), the highest records were obtained by the control followed by spraying $\mathrm{ZnSO}_{4}$ at $0.3 \%$ concentration when compared with the other treatments in both seasons. As for the interaction, the untreated Manfalouty trees gave the highest values in both seasons. Manfalouty cultivar had higher significant values in the total soluble tannin (\%) in both seasons.

Hamouda et al. (2015) found that foliar spraying nutrients had positive effect on leaves nutrient concentration and improved fruit chemical properties which related to the quality. The combined application of calcium (3\%) and boron $(0.25 \%)$ could be practiced for good growth and quality fruits of pomegranate (Sutanu, 2017). In addition, Sharma and Belsare (2009) mentioned that the total soluble solids, sugar contents were increased significantly with the application of boron at $0.2 \%$. Moazzam Anees et al. (2011) observed that, foliar application of $0.4 \% \mathrm{FeSO}_{4}+$ $0.8 \% \mathrm{H}_{3} \mathrm{BO}_{3}+0.8 \% \mathrm{ZnSO}_{4}$ gave the highest TSS, ascorbic acid, reducing sugars, non-reducing sugars, total sugar and minimum acidity as compared to the control. Njira and Nabwami (2015) pointed to an increase in fruit quality because of $\mathrm{Ca}, \mathrm{P}, \mathrm{Zn}$ and $\mathrm{Fe}$ are involved in enzyme synthesis, activation or as electron carriers while $\mathrm{Mg}$, and $\mathrm{K}$ are mostly involved in enzyme activation and transportation of materials such as fructose and sucrose from points of synthesis to sites of loading and hence affect quality.

\subsubsection{Juice (\%), vitamin Cand anthocyanin (juice)}

According to tabulated data in Table (9), generally Manfalouty $\mathrm{cv}$. produced the richest fruit juice in vitamin $\mathrm{C}$ and anthocyanin but lower in juice (\%).

Table (9): Effect of some nutrient applications on the percentages of juice (\%), vitamin (C) and total juice anthocyanin contents of Wardy and Manfalouty pomegranate trees during 2013 and 2014 seasons.

\begin{tabular}{|c|c|c|c|c|c|c|c|c|c|c|}
\hline \multirow{2}{*}{ No. } & \multirow[b]{2}{*}{ Treatments } & \multicolumn{3}{|c|}{ Juice $(\%)$} & \multicolumn{3}{|c|}{$\begin{array}{l}\text { Vitamin C (mg ascorbic } \\
\text { acid/100ml juice) }\end{array}$} & \multicolumn{3}{|c|}{$\begin{array}{l}\text { Total juice anthocyanin } \\
(\mathrm{mg} / 100 \mathrm{ml})\end{array}$} \\
\hline & & \begin{tabular}{|c|}
$\begin{array}{c}\text { Wardy } \\
\text { cv. }\end{array}$ \\
\end{tabular} & \begin{tabular}{|c|}
$* *$ Man. \\
cv.
\end{tabular} & \begin{tabular}{|c|}
$\begin{array}{c}\text { Mean } \\
(B)\end{array}$ \\
\end{tabular} & \begin{tabular}{|c|}
$\begin{array}{c}\text { Wardy } \\
\text { cv. }\end{array}$ \\
\end{tabular} & $\begin{array}{c}* * \text { Man. } \\
\text { cv. }\end{array}$ & $\begin{array}{c}\text { Mean } \\
(\text { B })\end{array}$ & \begin{tabular}{|c|}
$\begin{array}{c}\text { Wardy } \\
\text { cv. }\end{array}$ \\
\end{tabular} & $\begin{array}{c}* * * \text { Man. } \\
\text { cv. }\end{array}$ & $\begin{array}{c}\text { Mean } \\
\text { (B) }\end{array}$ \\
\hline & & \multicolumn{9}{|c|}{ First season: 2013} \\
\hline T1 & Control (farm fertilization) & $46.00 \mathrm{~b}$ & $43.00 \mathrm{c}$ & $44.50 \mathrm{~B}$ & $13.50 \mathrm{~g}$ & $24.00 \mathrm{~d}$ & $18.75 \mathrm{E}$ & $0.400 \mathrm{~h}$ & $0.617 \mathrm{~b}-\mathrm{d}$ & $0.510 \mathrm{D}$ \\
\hline T2 & Foliar spraying with $\mathrm{ZnSO}_{4}(0.3 \%)$ & $49.00 \mathrm{a}$ & $45.00 \mathrm{~b}$ & $47.50 \mathrm{~A}$ & $13.73 \mathrm{~g}$ & $24.33 \mathrm{~d}$ & $19.03 \mathrm{E}$ & $0.417 \mathrm{e}-\mathrm{g}$ & $0.640 \mathrm{a}-\mathrm{c}$ & $0.528 \mathrm{~B}$ \\
\hline T3 & $\begin{array}{l}\text { Foliar spraying with *mix. of } \\
\text { micronutrients at } 2 \mathrm{~g} / \mathrm{l}\end{array}$ & $9.20 \mathrm{a}$ & $45.10 \mathrm{~b}$ & $47.10 \mathrm{~A}$ & $13.83 \mathrm{~g}$ & $24.33 \mathrm{~d}$ & $19.08 \mathrm{E}$ & $0.420 \mathrm{e}-\mathrm{g}$ & $0.620 \mathrm{a}-\mathrm{d}$ & $0.520 \mathrm{BC}$ \\
\hline T4 & Soil application of $\mathrm{CaSO}_{4}$ at 50 & $49.30 \mathrm{a}$ & $5.20 \mathrm{~b}$ & $47.20 \mathrm{~A}$ & $14.73 \mathrm{f}$ & $25.33 \mathrm{c}$ & $20.03 \mathrm{C}$ & $0.430 \mathrm{ef}$ & $0.643 a-c$ & $0.537 \mathrm{AB}$ \\
\hline T5 & $\begin{array}{l}\text { Foliar spraying with } \mathrm{ZnSO}_{4}(0.3 \%)+ \\
\text { mix. of micronutrients at } 2 \mathrm{~g} / \mathrm{l}\end{array}$ & $9.40 \mathrm{a}$ & $45.20 \mathrm{~b}$ & $47.30 \mathrm{~A}$ & $14.00 \mathrm{~g}$ & $25.00 \mathrm{c}$ & $19.50 \mathrm{D}$ & $0.433 \mathrm{ef}$ & $0.653 \mathrm{ab}$ & $0.543 \mathrm{AB}$ \\
\hline T6 & \begin{tabular}{|l} 
Soil application of $\mathrm{Ca}$ \\
+ foliar spraying witl \\
\end{tabular} & $49.50 \mathrm{a}$ & $45.20 \mathrm{~b}$ & $47.30 \mathrm{~A}$ & $14.00 \mathrm{~g}$ & $25.33 \mathrm{c}$ & 19.67 CD & 0.430 ef & $0.657 \mathrm{ab}$ & $0.543 \mathrm{AB}$ \\
\hline T7 & $\begin{array}{l}500 \mathrm{~g} / \text { tree } \\
\mathrm{f}\end{array}$ & $49.50 \mathrm{a}$ & $45.20 \mathrm{~b}$ & $47.30 \mathrm{~A}$ & $14.66 \mathrm{f}$ & $26.66 \mathrm{~b}$ & 20.67 B & $0.453 \mathrm{e}$ & $0.677 \mathrm{a}$ & $0.565 \mathrm{~A}$ \\
\hline T8 & $\begin{array}{l}\text { Soil application } \mathrm{CaSO}_{4} \text { at } 500 \mathrm{~g} / \text { tree }+ \\
\text { foliar spraying } \mathrm{ZnSO}_{4}(0.3 \%)+\text { mix. } \\
\text { of micronutrients at } 2 \mathrm{~g} / \mathrm{l}\end{array}$ & $49.60 \mathrm{a}$ & $45.30 \mathrm{~b}$ & $47.90 \mathrm{~A}$ & $16.66 \mathrm{e}$ & $27.33 \mathrm{a}$ & 21.99 A & $0.480 \mathrm{e}$ & $0.673 \mathrm{a}$ & $0.577 \mathrm{~A}$ \\
\hline \multicolumn{2}{|r|}{ Mean (A) } & $48.94 \mathrm{~A}$ & $44.90 \mathrm{~B}$ & & $14.39 \mathrm{~B}$ & $25.29 \mathrm{~A}$ & & $0.433 \mathrm{~B}$ & $0.647 \mathrm{~A}$ & \\
\hline & & \multicolumn{9}{|c|}{ Second season: 2014} \\
\hline T1 & Contr & $47.00 \mathrm{c}$ & $43.00 \mathrm{~d}$ & $45.00 \mathrm{~B}$ & $14.07 \mathrm{ij}$ & $24.67 \mathrm{ef}$ & $19.37 \mathrm{C}$ & $0.420 \mathrm{f}$ & $0.630 \mathrm{a}-\mathrm{c}$ & $0.525 \mathrm{DE}$ \\
\hline $\mathbf{T 2}$ & Foliar spraying with $\mathrm{ZnSO}_{4}$ & $50.00 \mathrm{a}$ & $48.00 \mathrm{~b}$ & $49.00 \mathrm{~A}$ & $13.83 \mathrm{j}$ & $25.33 \mathrm{~cd}$ & $19.58 \mathrm{C}$ & $0.417 \mathrm{f}$ & $0.653 \mathrm{ab}$ & $0.535 \mathrm{D}$ \\
\hline T3 & $\begin{array}{l}\mathbf{F} \\
\mathrm{n}\end{array}$ & $0.10 \mathrm{a}$ & $48.10 \mathrm{~b}$ & $\mathbf{A}$ & $14.17 \mathrm{ij}$ & $24.67 \mathrm{bc}$ & $15.25 \mathrm{D}$ & $0.417 \mathrm{f}$ & $0.627 \mathrm{a}-\mathrm{c}$ & $0.528 \mathrm{DE}$ \\
\hline T4 & Soil applicat & $50.20 \mathrm{a}$ & $48.10 \mathrm{~b}$ & $49.10 \mathrm{~A}$ & $14.50 \mathrm{ij}$ & $24.33 \mathrm{f}$ & $\mathrm{C}$ & $0.437 \mathrm{de}$ & $0.650 \mathrm{ab}$ & $0.543 \mathrm{C}$ \\
\hline T5 & $0.3 \%+$ & $50.30 \mathrm{a}$ & $48.10 \mathrm{~b}$ & $49.20 \mathrm{~A}$ & $14.67 \mathrm{i}$ & $25.67 \mathrm{bc}$ & 20.17 B & $0.450 \mathrm{e}-\mathrm{g}$ & $0.667 \mathrm{ab}$ & $0.558 \mathrm{BC}$ \\
\hline T6 & \begin{tabular}{|l}
$\begin{array}{l}\text { Soil application of } \mathrm{Ca} \\
+ \text { foliar spraying witl }\end{array}$ \\
\end{tabular} & $50.30 \mathrm{a}$ & $48.20 \mathrm{~b}$ & $49.20 \mathrm{~A}$ & $14.50 \mathrm{ij}$ & $25.00 \mathrm{de}$ & $19.75 \mathrm{BC}$ & $0.520 \mathrm{~d}$ & $0.650 \mathrm{ab}$ & 0.585 AB \\
\hline T7 & $\begin{array}{l}\text { Soil application of } \mathrm{CaSO}_{4} \text { at } 500 \mathrm{~g} / \text { tree } \\
+ \text { foliar spraying with mix. of } \\
\text { micronutrients at } 2 \mathrm{~g} / \mathrm{l}\end{array}$ & $50.30 \mathrm{a}$ & $48.20 \mathrm{~b}$ & $49.20 \mathrm{~A}$ & $14.20 \mathrm{ij}$ & $26.00 \mathrm{~b}$ & 20.10 B & $0.463 \mathrm{~d}-\mathrm{f}$ & $0.657 \mathrm{ab}$ & $0.560 \mathrm{~B}$ \\
\hline T8 & $\begin{array}{l}\text { Soil application } \mathrm{CaSO}_{4} \text { at } 500 \mathrm{~g} / \text { tree }+ \\
\text { foliar spraying } \mathrm{ZnSO}_{4}(0.3 \%)+\text { mix. } \\
\text { of micronutrients at } 2 \mathrm{~g} / \mathrm{l}\end{array}$ & $50.30 \mathrm{a}$ & $48.20 \mathrm{~b}$ & $49.20 \mathrm{~A}$ & $15.33 \mathrm{~h}$ & $27.33 \mathrm{a}$ & $21.33 \mathrm{~A}$ & $0.480 \mathrm{de}$ & $0.700 \mathrm{a}$ & $0.590 \mathrm{~A}$ \\
\hline & Mean (A) & $49.80 \mathrm{~A}$ & $47.50 \mathrm{~B}$ & & $14.41 \mathrm{~B}$ & $25.38 \mathrm{~A}$ & & 0.452 B & $0.654 \mathrm{~A}$ & \\
\hline
\end{tabular}

Means followed by the same letter in a column or row do not differ significantly according to Duncan's New

Multiple Range Test at $\mathrm{P}=0.05-----*$ mix. of micronutrients $=(\mathrm{Mg}+\mathrm{Fe}+\mathrm{Zn}+\mathrm{Mn}+\mathrm{Cu}+\mathrm{B}+\mathrm{Mo}+\mathrm{S})$

$* *$ Man. = Manfalouty cultivar-----(A) $=$ Cultivars $(\mathrm{B})=$ Nutrient applications 
The specific effect of the tested treatments showed that, soil application of $\mathrm{CaSO} 4$ at 500 $\mathrm{g} /$ tree + spraying mix. of micronutrients at $2 \mathrm{~g} / 1$ either with or without spraying $\mathrm{ZnSO}_{4}$ at $0.3 \%$ proved to be the best treatments in vitamin $\mathrm{C}$ and anthocyanin juice contents during the two seasons of study. In contrast, it was so obvious to be notice that, the untreated trees had the poorest fruits in juice (\%), vitamin $\mathrm{C}$ and anthocyanin. As for the interaction between the treatments and both cultivars, the untreated Manfalouty trees were the lowest in fruit juice (\%) in both seasons. Whereas, the untreated trees (control) with Wardy cultivar caused a highly significant decrease in juice vitamin $\mathrm{C}$ and anthocyanin (\%) content compared with the other treatments. It is also worthy to notice that, the treated Manfalouty trees with soil application of $\mathrm{CaSO}_{4}$ at $500 \mathrm{~g} /$ tree + spraying mix. of micronutrients at $2 \mathrm{~g} / 1+$ spraying $\mathrm{ZnSO}_{4}$ at 0.3 $\%$ produced the richest fruits in vitamin $\mathrm{C}$ and anthocyanin juice contents in 2013 and 2014 growing seasons.

El-Akkad et al. (2016) and Sutanu et al. (2017) stated that, the combined application of calcium and boron $(0.25 \%)$ could be practiced for good quality fruits of pomegranate. Also, Tanuja et al. (2016) reported that the combination of boric acid and zinc sulphate $0.4 \%$ each gave superior fruit quality of pomegranate. The improvement in quality of fruits might be due to the catalytic action of micronutrients particularly at higher concentrations. Hence, the foliar application of micronutrients quickly increased the uptake of macronutrients in the tissues and improves fruit quality (Anees et al., 2011).

\section{Conclusion}

For controlling fruit cracking and at the same time improving yield and fruit quality in pomegranate (Wardy and Manfalouty cvs.) grown under Souhag governorate conditions, it is advised to use soil application of calcium sulfate at $500 \mathrm{~g} /$ tree and foliar spraying with zinc sulfate $(0.3 \%)$ and mix. of micronutrients at 2 $\mathrm{g} / \mathrm{l}$.

\section{REFERENCES}

A.O.A.C. (1985). Official Methods of Analysis. Association of Official Analysis Chemist. Published by A.O.A.C. Washington, D.C. U.S.A.

Abd El-Rhman I.E. (2010). Physiological studies on cracking phenomena of pomegranates. J. Appl. Sci. Res., 6 (6): 696-703.
Ahmed D. D., Mustafa O., Kenan D., Nurcan E. and Coskun D. (2009). Antimicrobial activity of six pomegranate (Punica granatum $\mathrm{L}$.) varieties and their relation to some of their pomological and phytonutrient characteristics. Mole., 14: 18081817.

Anees M., Tahir F.M., Shahzad J. and Mahmood N. (2011). Effect of foliar application of micronutrients on the quality of mango (Mangifera indica L.) cv. Dusehri fruit. Mycopath., 9: 25-28.

Amit P., Sharad G., MohdAyub A. and Ajay A. (2014). Rans formation of mineral nutrients and phenolics. Pomegranate (Punica grantum L) Fruit. Vol. 4/Issue 5: 271-278.

Ashwini G. (2005). Controlling cracking of pomegranate by spraying calcium hydroxide. www. agriculture information.

Dinkar K. R. (2010). Some potential benefits and medicinal uses of pomegranate. Dave's Garden,davesgarden.com/guides/articles/view/ 888.

Duncan D. B. (1955). Multiple range and multiple F. Tests. Biometrics, 11: 1-41.

Ed S. and Eric W.M. (2007). The Pomegranate: A New Look at the Fruit of Paradise Hortsci., 42 (5): 1088-1092.

El-Akkad M.M., Fatma El-Zahraa M. G. and Ibrahim R.A. (2016). Effect of $\mathrm{GA}_{3}$, calcium chloride and vapor guard spraying on yield and fruit quality of manfalouty pomegranate trees. Assiut J. Agric. Sci., 47 (6-1): 181-190.

El-Khawaga A.S. (2007). Reduction in fruit cracking in Manfalouty pomegranate following a foliar application with paclobutrazol and zinc sulphate. J. Appl. Sci. Res., 3 (9): 837-840,

Guneri M., Yildiztekin M., Tuna A. L. and Yokas I. (2016). Calcium and potassium fertilization on antioxidant capacity and the fruit quality of 'Hicaz' pomegranates (Punica granatum L.). Bul. J. Agric. Sci.; 22 (4):591-599.

Hamouda H. A., Elham Z. A. and Nagwa G. Z. (2015). Nutritional Status and Improving fruit quality by potassium,magnesium and manganese foliar application in pomegranate shrubs. Int;1 . J. Chem. Tech. Res.,.8 (6): 858-867.

Hepaksoy S., Aksoy U., Can H. Z. and UI M.A. (2000). Determination of relationship between fruit cracking and some 
physiological responses, leaf characteristics and nutritional status of some pomegranate varieties. CIHEAM-IAMZ. 5: 87-92.

Hsia C. L., Luh B. S. and Chickester C. O. (1965). Anthocyanin in Freestone peaches. J. Food Sci., 30:5-12.

Hoda A.K. and Hoda S.H.A. (2013). Cracking and fruit quality of pomegranate (Punica granatum L.) as affected by pre-harvest sprays of some growth regulators and mineral nutrients. J. Hort. Sci. Ornam. Plants, 5 (2): 71-76.

Ibrahim M. I. (2010). Efficiency of pomegranate peel extract as antimicrobial, antioxidant and protective agents. World J. Agric. Sci., 6 (4), 338-344.

John C. and Lauren C. G. (2011). Foliar nutrient sprays affect early harvest season fruit cracking of 'Wonderful' Pomegranate. jchater@calpoly.edu, California Polytechnic Institute and State Univ.

Kharsandi F., Yazdi F.A. and Vazifehshenas M.R. (2009). Foliar zinc fertilization improves marketable fruit yield and quality attributes of pomegranate. Int'l. J. Agric. Biol., 11: 766-770.

Koriem M. A., Khalifa M. R., Ibrahim M. M. and Hammad E. (1994). Re-use of drainage water and application of gypsum mixed with lime in reclamation of saline sodicmagnesic soils. Monofiya. J. Agric. Res., 19: 699-714.

Korkmaz N. and Askn M. A. (2015). Effects of calcium and boron foliar application on pomegranate (Punica granatum L.) fruit quality, yield, and seasonal changes of leaf mineral nutrition. Acta Hort.; 25: 413-422.

Kuldeep K., Joon M.S. and Sihog R.P. (2001). Effect of micronutrients and growth regulator on pre-mature and mature cracking of pomegranate var. Jodhpur Red. Haryana J. Hort. Sci., 30 (3/4): 207208.

Moazzam-Anees T. F.M., Shahzad J. and Mahmood N. (2011). Effect of foliar application of micronutrients on the quality of mango (Mangifera indica L.) cv. Dusehri Fruit. Mycopath, 9 (1): 25-28.

Morsy M.H., Abdelaal A.M.K. and Abdelaal H.A. (2008). Attempts to find best preharvest treatment required for obtaining marketable fruits and its effect on storage life of Manfalouty pomegranates 1Evaluating of some soil and foliar treatments on splitting, sunburn, yield and fruit quality. Minia J. Agric. Res.Dev. 23 (1), 263-293.

Njira K. O. W. and Nabwami J. (2015). A review of effects of nutrient elements on crop quality. Afri. J. Food, agric., Nutr. and Develop. 15 (1): 9777-9793.

Nita M. (2009). Medicinal Properties of the Pomegranate. Nutrition. Food Facts. www.wellbox.com.

Pande Y. A., Rehalia A. S. and Pathak S. A. (2012). Effect of zinc and boron on fruit setting, yield and quality of pomegranate (Punica granatum). Current Adv. Agric. Sci.; 4 (2): 176-177.

Pedro M., García-Viguera C., Javier N., Diego A. M., Julián B., Domingo S. and Nuria M. (2011). Photochemical characterization for industrial use of pomegranate (Punica granatum L.) cultivars grown in Spain. J. Sci. And Food Agric., 91 (10): 18931906.

Rakesh K., Parshant B. and Srivastava J. N. (2010). Fruit Cracking: A Challenging Problem of Fruit Industry. In: Jeyakumar P. Physiological Disorders in fruit crops. Horticultural College and Research Institute, Tamil Nadu Agric. Univ., Coimbatore - 641:003.

Rani R. and Brahmachari V.S. (2001). Effect of foliar application of calcium, zinc and boron on cracking and physio-chemical composition of litchi. Orissa J. Hort., 29: 50-54.

Seidhom S.H. and Abd-El-Rahman G. (2011). Prediction of traditional climatic changes effect on pomegranate trees under desert condition in EL-Maghara, Egypt. J. Amer. Sci., 7(5): 268-280.

Sharma N. and Belsare C. (2009). Effect of plant bio-regulators and nutrients on fruit cracking and quality on pomegranate (Punica granatum L.) 'G-137'. In: Himachal Pradesh. ISHS Acta Horticulturae 890: II International Symposium on Pomegranate and Minor Mediterranean - Fruits: ISPMMF.

Sheikh M. K. and Manjula N. (2012). Effect of chemicals on control of fruit cracking in pomegranate (Punica granatum L.) var. Ganesh Options Mediterranean's. Serie A, Seminaries Mediterranean's, 103:133-135.

Shivanandam V. N., Pradeep S. L., Rajanna K. and Shivappa M. (2007). Effect of zinc sulphate on growth and yield of mango varieties and hybrids. J. Soil Crops., 17: 
225-229.

Singh J. and Maurya A. N. (2004). Effect of micronutrients on bearing of mango (Mangifera indica) cv. Mallika. Prog. J. Agric., 4 (1):47-50.

Singh H.K., Srivastava A. K., Dwivedi R. and Kumar P. (2001). Effect of foliar feeding of micronutrients on plant growth, fruit quality, yield and internal fruit necrosis of aonla (Emblica officinalis Gaertn.) cv. Francis.Prog. J. Hort., 33(1): 80-83.

Snedecor G. W. and Cochran W. G. (1980). Statistical Methods, $7^{\text {th }}$ ed ., Iowa State Univ. Press, Iowa, USA, pp.85-86.

Sourour M. M. (2000). Effect of foliar application of some micronutrient forms on growth, yield, fruit quality and leaf mineral composition of Valencia orange trees grown in North Sinai. Alex. J. Agric. Res., 45 (1) : 269-285.
Sutanu M., Aniruddha Y. and Meena K.R. (2017). Effect of calcium and boron on growth, yield and quality. International J. Plant Sci., Vol. 12 (2). 108-113.

Tanuja R. D. K. and Rawat S. S. (2016). Effect of foliar application of zinc and boron on yield and quality of pomegranate (Punica granatum L.) cv. Ganesh under subtropical conditions of Garhwal hills. Hort. Flora Res. Spect. 5 (1): 61-64. 16.

Winton A. H. and Winton K. B. (1945). Analysis of Food. Wiley, New York. U.S.A. PP. 572.

Yadav V. K., Jain M. C., Sharma M. K., Gupta N. K. and Singh J. (2014). Effect of micronutrients foliar feeding on growth and yield of pomegranate (Punica granatum L.) cv. Sindhuri. Int'l. J. Trop. Agric.; 32 (3/4):469-473.

\footnotetext{
تأثير الكالسيوم وبعض العناصر المغذية علي تثظق ثمار الرمان تحت ظروف محافظة سوهاج

طارق خلف البلك - مدلين راشد سورسن

قسم بحوث الزيتون وفاكهة المناطق شبه جافه ـ معهد بحوث البساتين ـ مركز البحوث الزر اعبة ـ الجيزة ـ مصر

ملخص تصن

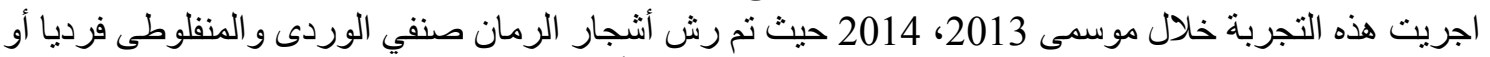

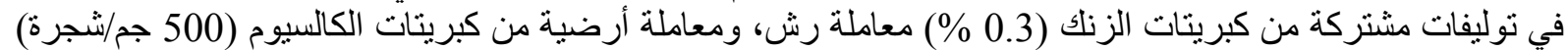

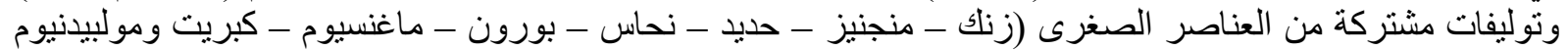

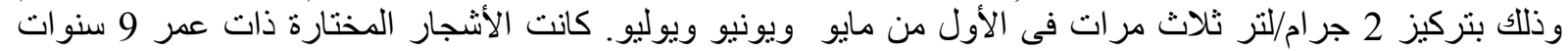

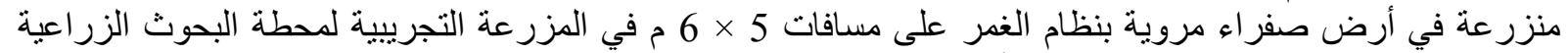

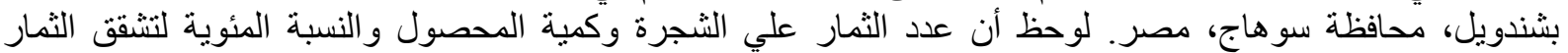

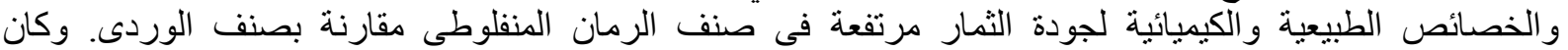

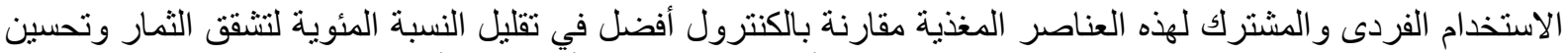

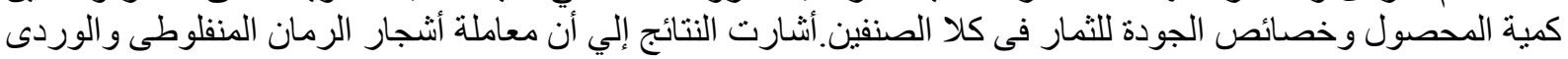

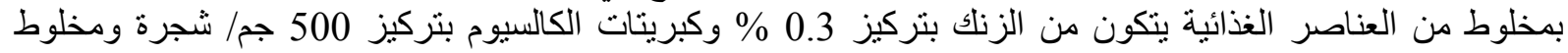
العناصر المغذية بالتركيزات وفى المو اعيد الموضحة يكون فعال بشكل كبير في تقليل النسبة المئوية لتشقق الثمار ويساعد

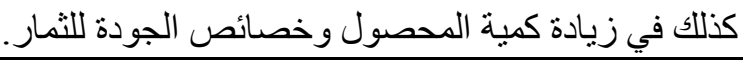

